The Effects of Technical Change on Labor Market Inequalities

by

\author{
Andreas Hornstein, Federal Reserve Bank of Richmond \\ Per Krusell, Princeton University, IIES, \\ CAERP, CEPR, and NBER \\ Giovanni L. Violante, New York University and CEPR \\ CEPS Working Paper No. 113 \\ July 2005
}

This is an abridged version of a chapter in the forthcoming Handbook of Economic Growth (Philippe Aghion and Steven Durlauf, editors). We are grateful to Philippe Aghion for his suggestions on how to improve an early draft. We thank Stephan Fahr, Giammario Impullitti, Matthew Lindquist, and John Weinberg for comments, Hubert Janicki for research assistance and Eva Nagypal and Bruce Weinberg for providing their data. Krusell thanks the NSF and Princeton's Center for Economic Policy Studies for research support. Violante thanks the CV Starr Center for research support. Any opinions expressed are those of the authors and do not necessarily reflect those of the Federal Reserve Bank of Richmond or the Federal Reserve System. For correspondence, our e-mail addresses are: andreas.hornstein@rich.frb.org, pkrusell@princeton.edu, and gianluca.violante@nyu.edu. 


\title{
The Effects of Technical Change on Labor Market Inequalities*
}

\author{
Andreas Hornstein ${ }^{\dagger} \quad$ Per Krusell ${ }^{\ddagger} \quad$ Giovanni L. Violante ${ }^{\S}$
}

First Draft: September 24, 2003

This Draft: December 6, 2004

\begin{abstract}
In this chapter we inspect economic mechanisms through which technological progress shapes the degree of inequality among workers in the labor market. A key focus is on the rise of U.S. wage inequality over the past 30 years. However, we also pay attention to how Europe did not experience changes in wage inequality but instead saw a sharp increase in unemployment and an increased labor share of income, variables that remained stable in the U.S. We hypothesize that these changes in labor market inequalities can be be accounted for by the wave of capitalembodied technological change, which we also document. We propose a variety of mechanisms based on how technology increases the returns to education, ability, experience, and "luck" in the labor market. We also discuss how the wage distribution may have been indirectly influenced by technical change through changes in certain aspects of the organization of work, such as the hierarchical structure of firms, the extent of unionization, and the degree of centralization of bargaining. To account for the U.S.-Europe differences, we use a theory based on institutional differences between the United States and Europe, along with a common acceleration of technical change. Finally, we briefly comment on the implications of labor market inequalities for welfare and for economic policy.
\end{abstract}

Keywords: Inequality, Institutions, Labor Market, Skills, Technological Change.

JEL Classification: D3, J3, O3.

${ }^{*}$ This is an abridged version of a chapter in the forthcoming Handbook of Economic Growth (Philippe Aghion and Steven Durlauf, Editors). We are grateful to Philippe Aghion for his suggestions on how to improve an early draft. We thank Stephan Fahr, Giammario Impullitti, Matthew Lindquist, and John Weinberg for comments, Hubert Janicki for research assistance and Eva Nagypal and Bruce Weinberg for providing their data. Krusell thanks the NSF and Princeton's Center for Economic Policy Studies for research support. Violante thanks the CV Starr Center for research support. Any opinions expressed are those of the authors and do not necessarily reflect those of the Federal Reserve Bank of Richmond or the Federal Reserve System. For correspondence, our e-mail addresses are: andreas.hornstein@rich.frb.org, pkrusell@princeton.edu, and gianluca.violante@nyu.edu.

${ }^{\dagger}$ Federal Reserve Bank of Richmond.

${ }^{\ddagger}$ Princeton University, Institute for International Economic Studies, CAERP, CEPR, and NBER.

$\S$ New York University and CEPR. 


\section{Introduction}

In this chapter we discuss the recent three decades of data on technology, productivity, and labor market outcomes. In particular, we explore the hypothesis that technological change has affected the labor market in various ways. We argue that (i) there is ample evidence indicating significant capital-embodied and/or skill-biased technological change and that (ii) this kind of technological change would plausibly lead to many of the transformations in the labor markets that we have observed. On the one hand, we are interested in possible implications of non-neutral technological change - of the kind we think we have experienced - on variables like wage inequality, unemployment, labor share, and unionization. On the other hand, we explore the possibility that the labor market can be used as an additional source of evidence of non-neutral technological change, a testing ground of sorts.

The past 30 years are particularly informative because they have contained rather important trend changes in several variables. We have seen a productivity slowdown common to all industrialized countries and common to almost all industries, together with continuing structural change away from manufacturing and toward services. An exception to this widespread productivity slowdown was the fast and accelerating productivity growth of in the industries producing investment goods, in particular those producing equipment. Only very recently has there been a more widespread acceleration of productivity growth. Of course, in this context we are arguably in the midst of an "Information Technology Revolution." We also discuss evidence of changes in the workplace-in how production within firms is organized-possibly reflecting underlying changes in technology.

In the labor market, we have seen a sharp increase in wage inequality in the United States contrasting a roughly flat development in Europe, whereas we have witnessed a strong increase in European unemployment and no trend in U.S. unemployment. ${ }^{1}$ The organization of labor markets seems to have changed too: for example, unions have lost prevalence during this period, and to the extent there have been unions, centralized bargaining has been replaced by decentralized bargaining in many sectors. Are all these developments consistent with basic economic theory and a short list of underlying technological driving forces? We argue that they are. To make our argument more convincing, we also put the past three decades in a historical perspective, going back as far as the early 20th century with data on technological change and the skill premium.

One distinctive feature of this literature is that the many different ideas have been presented in a wide variety of theoretical frameworks ranging from the neoclassical Ramsey-Cass-Koopmans growth model to the Schumpeterian endogenous growth model; from the traditional McCall search

\footnotetext{
${ }^{1}$ Although the word inequality literally would suggest a zero-one classification - either there is inequality or there is equality - we will use the term loosely to reflect some measure of dispersion. That is, we will attach quantifiers such as "more" or "less" to the word.
} 
model to the Lucas-Prescott island economy; from the Mortensen-Pissarides matching model to the competitive directed search framework; and from the Bewley-Aiyagari incomplete-markets model to Arrow-Debreu economies with limited enforcement. We think two main reasons exist for the lack of a unified framework of analysis. First, this field of research is still relatively young; second, departing from the competitive model in studying labor markets is fairly natural, and many alternative frameworks exist that incorporate frictions. The main drawback of the lack of a unifying framework - we will repeat it often in the chapter - is that making structurally based quantitative comparisons between different mechanisms is difficult.

To us, these heterogeneous approaches pose a formidable challenge in the exposition. Our solution has been to give priority to presenting a range of ideas, using a variety of theoretical setups, rather than to discuss in great detail a few more specific frameworks. This approach has necessitated a summarization of some rather rich models in a few key equations, which misses some of the elegance and richness of the original frameworks. We hope, however, that our spanning a wide spectrum of ideas and macroeconomic effects of technological change helps paint a picture that is broader and that, at least in an impressionistic way, suggests that the main underlying hypothesis we are proposing is quite reasonable.

The presentation of the ideas in this chapter is organized into four parts. In the first part, Section 2, we review the main trends in the data on technological change and labor market inequalities. We then cover two kinds of theories that could account for the data.

In the second part of the chapter we cover "neoclassical" theory (i.e., models where wages directly reflect marginal productivity). We view the firm as hiring labor of different skill levels in a competitive and frictionless labor market. Wages, thus, will be influenced by technology in a very direct way. Similarly, the returns to education, ability, and experience will be directly tied to changes in technology. Therefore, within these kinds of theories, the shape of the production function of the firm is crucial. We then move beyond the production function of the firm or, rather, we attempt to go inside it. In particular, Section 4 explores the possibility that the organization of the workforce also has changed within firms. These transformations, of which there is some documentation, are arguably also a result of the kind of technological change we look at in this chapter. We point, in particular, to a recent literature that explores how firms are organized and how the IT revolution, by inducing organizational changes in the firm, had a substantial impact on wage inequality.

The second class of theories we cover, in the third part of the chapter, relies more on frictions in the labor market and deals more directly with how this market is organized. Here, technological change can still directly influence wages but there are new channels. For one, wages may not only reflect marginal productivity. Moreover, now unemployment is more in focus and is a function of 
technology, and since unemployment - through workers' outside option-may also feed back into wages, the picture becomes yet more complex. In the context of how wages are set, we furthermore argue in Section 5 that the importance of unions and their modus operandi are influenced by technology and, more generally, that labor income as a share of total income may respond to technological change in the presence of unions. Finally, government participation in labor marketslabor-market "institutions," in the form of unemployment benefits, firing costs, and so on-likely interacts with technology in determining outcomes, and Section 6 completes the third part of this chapter by analyzing the interaction between technological shocks and labor market institutions in the context of the comparison between the United States and Europe.

The fourth and final part of the chapter asks the "So what?" question: given the significant transformations observed, is a government policy change called for? Our discussion here is very brief. It mainly points out that a basic element underlying any decisions on policy, namely, what the welfare outcomes of the changes in wages, unemployment, and so on, are for different groups in society, is studied only partially in the literature so far. Studies of changes in expected lifetime income of different groups exist, but it is reasonable to assume that risk matters too, especially with trend changes as large as those observed (at least to the extent they are hard to foresee and insure). Finally, Section 7 concludes the chapter.

\section{A Look at the Facts}

Before modeling the economic forces that connect changes in technology to labor market outcomes, it is useful to begin by summarizing how labor market inequalities and the aggregate technological environment evolved over the past three decades.

\subsection{Labor Market Inequalities}

In the late 1980s and early 1990s, an extensive body of empirical work has started to systematically document the changes in the wage structure over the past three decades. Levy and Murnane (1992) give the first overview of an already developed empirical literature. To date, Katz and Autor (1999) and, more recently, Eckstein and Nagypal (2004), offer the most exhaustive description of the facts. In between, numerous other papers have contributed significantly to our understanding of the data on wage inequality. ${ }^{2}$

The typical data source used in the empirical work on the subject is the sequence of yearly cross-sections in the March Current Population Survey (CPS). The other important data source is the longitudinal Panel Study of Income Dynamics (PSID). In this section, we limit ourselves to

\footnotetext{
${ }^{2}$ We refer the reader to the bibliographic lists in Levy and Murnane (1992), Katz and Autor (1999), and Eckstein and Nagypal (2004) for more details.
} 
stating the main facts and briefly commenting on them, omitting the details on the data sets, the sample selection, and the calculations that can be found in the original references. Unless otherwise stated, the data refer to a sample of male workers with strong attachment to the labor force, i.e., full-time, full-year workers. ${ }^{3}$

Observation 1 Wage inequality in the United States is today at its historical peak over the post World War II period. However, early in the century it was even larger. The returns to college and high school fell precipitously in the first half of the century and then rose again until now (Goldin and Katz, 1999).

In other words, the time series for inequality over the past 100 years is "U-shaped." Although the bulk of this chapter is devoted to interpreting the dynamics of the wage structure over the past three decades, it is useful to put the evidence in a historical perspective to appreciate that the high current level of inequality is not a unique episode in U.S. history. The rest of the facts characterize the evolution of inequality since the mid 1960s. ${ }^{4}$

Observation 2 Wage inequality increased steadily in the United States starting from the early 1970s. The 90-10 weekly wage ratio rose by 35 percent for both males and females in the period 1965-1995: from 1.20 to 1.55 for males, and from 1.05 to 1.40 for females. The increase in inequality took place everywhere in the wage distribution: both the 90-50 differential and the 50-10 differential rose by comparable amounts (Katz and Autor, 1999).

Qualitatively, the rise in inequality is present independently of the measure of dispersion and of the definition of labor income. For example, the standard deviation of log wages for males rose from 0.47 in 1965 to 0.62 in 1995, the Gini coefficient jumped from 0.25 to 0.34 (Katz and Autor, 1999), and the mean-median ratio rose from 1.00 to 1.18 over the same period (Eckstein and Nagypal, 2004). Inequality of annual earnings increased even more. ${ }^{5}$

Observation 3 The average and median wage have remained constant in real terms since the mid-1970s. Real wages in the bottom of the wage distribution have fallen substantially. For

\footnotetext{
${ }^{3}$ Eckstein and Nagypal (2004) systematically document all the facts for males and females separately. Typically, measures of inequality in the literature refer to hourly or weekly wages, that is, they isolate the evolution of the "price" of certain labor market skills. The use of hourly or weekly wages then avoids the contamination of the data with endogenous labor supply decisions that, for example, is present in annual earnings.

${ }^{4}$ In Section 4, we return briefly to this historical pattern. In passing, we note that the data seems at odds with the so-called "Kuznets Hypothesis," i.e., the conjecture that income inequality first increases and then decreases as economies grow.

${ }^{5}$ The reason is, perhaps surprisingly, not a rise in the cross-sectional variance of hours worked, but rather a substantial increase in the wage-hours correlation over the past 30 years. See Heathcote et al. (2003) for an account of these facts.
} 
example, the 10th wage percentile for males declined by 30 percent in real terms from 1970 to 1990 (Acemoglu, 2002a). ${ }^{6}$ On the contrary, salaries in the very top of the wage distribution have grown rapidly. In 1970, the workers in the top 1 percent of the wage distribution held 5 percent of the U.S. wage bill, whereas in 1998 they received over 10 percent (Piketty and Saez, 2003).

A large part of the absolute increase of top range salaries is associated with the surge in CEO compensation. Piketty and Saez (2003) document that in 1970 the pay of the top 100 CEOs in the United States was about 40 times higher than the average salary. By 2000 those CEOs earned almost 1,000 times the average salary.

We now list a set of facts on the evolution of between-group inequality, i.e. inequality between groups of workers classified by observable characteristics (e.g., gender, race, education, experience, occupation). For this purpose, it is useful to write wages $w_{i t}$ using the Mincerian representation

$$
\ln w_{i, t}=X_{i, t}^{\prime} p_{t}+\omega_{i t}
$$

where $X_{i t}$ is a vector measuring the set of observable features of individual $i$ at time $t, p_{t}$ can be interpreted as a vector of prices for each characteristic in $X$, and $\omega_{i t}$ is the residual unobserved component.

Observation 4 The returns to education increased slightly from 1950 to 1970, fell in the 1970s, increased sharply in the 1980s, and continued to increase, although at a slower pace, in the 1990s. For example, the college wage premium - defined as the ratio between the average weekly wage of college graduates (at least 16 years of schooling) and that of workers with at most a high school diploma (at most 12 years of schooling) — was 1.45 in 1965, 1.35 in 1975, 1.50 in 1985, and 1.70 in 1995 (Eckstein and Nagypal, 2004). If one estimates the coefficient on educational dummies in a standard Mincerian wage regression like (1), the finding is similar: the annual return to a college degree (relative to a high-school degree) was 33 percent in the 1980s and over 50 percent in the 1990s (Eckstein and Nagypal 2004).

We plot the college wage premium over the period 1963-2002 in Figure 1 (top panel). ${ }^{7}$ Interestingly, if one slices up the college-educated group more finely into workers with post-college degrees and workers with college degree only, the rise in the skill premium is still very apparent. The return

\footnotetext{
${ }^{6}$ Note, however, that the wages of the 10 th wage percentile have started to increase again since the late $1990 \mathrm{~s}$ (Eckstein and Nagypal, 2004).

${ }^{7}$ Authors differ in their treatment of workers who have attended college for some years, but did not obtain a college degree. In Figure 1 (top panel), we have followed the bulk of the literature and assigned half of them to the numerator and half of them to the denominator (e.g., Autor et al. 1998).
} 
to post-college education relative to college education doubled from 1970 to 1990 (Eckstein and Nagypal 2004).

\section{FIGURE 1}

Observation 5 The returns to professional and white-collar occupations relative to blue-collar occupations display dynamics and magnitudes similar to the data stratified by education. For example, the professional-blue collar premium rose by 20 percent from 1970 to 1995 (Eckstein and Nagypal 2004).

Occupation is an interesting dimension of the wage structure that, until recently, received very little attention. For example, the "returns to occupation" appear large and significant, over and beyond returns to education.

Observation 6 The returns to experience increased in the 1970s and the 1980s and leveled off in the 1990s. For example, the ratio of weekly wages between workers with 25 years of experience and workers with 5 years of experience rose from 1.3 in 1970 to 1.5 in 1995 (Katz and Autor, 1999). An analysis by education group shows that the experience premium rose sharply for high-school graduates but remained roughly constant for college graduates (Weinberg, 2003b).

It is worth emphasizing, that although entry of the baby-boomers into the labor market in the early 1970s had a significant impact on the experience premium, the dynamics described above are robust to this and other demographic effects. See for example, Juhn et al. (1993). ${ }^{8}$

Observation 7 Inequality across race and gender declined since 1970. The black-white race differential, for workers of comparable experience, fell from 35 percent in 1965 to 20 percent in 1990 (Murphy and Welch, 1992). The female-male wage gap fell from 45 percent in 1970 to 30 percent in 1995 (Katz and Autor, 1999).

We plot of the gender wage gap over the period 1963-2002 in Figure 1 (bottom panel). A unifying theory of the changes in the wage structure based on technological change should have something to say about gender as well as race. Admittedly, these two dimensions of inequality have been largely neglected by the literature.

Observation 8 The composition of the working population changed dramatically over the past 40 years: in the period 1970-2000, women's labor force participation rate rose from 49 percent

\footnotetext{
${ }^{8}$ More recently, however, Card and Lemieux (2001) have argued in support of some "vintage effects" in the return to education. In particular, they argue that the college-high school premium is somewhat larger among the most recent cohorts of young workers entering the labor market.
} 
to 73 percent; college graduates rose from 15 to 30 percent of the male labor force and from 11 to 30 percent of the female labor force; professionals soared from 24 to 33 percent of the male labor force and from 8 to 28 percent of the female labor force (Eckstein and Nagypal, 2004).

We plot the relative supply of skilled workers and female workers over the time period 1963-2002 in Figure 1 (top and bottom panel, respectively). ${ }^{9}$

In terms of equation (1), one can define the between-group component of wage inequality as the cross-sectional variance of $X_{i t}^{\prime} p_{t}$, and the within-group component as the variance of the residual $\omega_{i t}$. The fraction accounted for by observable characteristics, in turn, can be decomposed into what is caused by a change in the dispersion in the quantities of observable characteristics $\left(X_{i t}\right)$, for given vector of prices, and what is due to a change in the prices associated to each observable characteristic $\left(p_{t}\right)$, for a given distribution of quantities.

Observation 9 Overall, changes in quantities and prices of observable characteristics (gender, race, education, experience) explain about 40 percent of the increase in the variance of log wages from 1963 to 1995. The price component is by far larger than the quantity component. Increasing within-group inequality, i.e., wage dispersion within cells of "observationally equivalent" workers accounts for the residual 60 percent of the total increase. With respect to the timing, the rise in within-group inequality seems to anticipate that of the college premium by roughly a decade (Juhn et al. 1993). ${ }^{10}$

One can specify further the structure of the residual $\omega_{i t}$ of equation (1), for example as

$$
\omega_{i t}=\phi_{t} \alpha_{i}+\varepsilon_{i t}
$$

where $\alpha_{i}$ is the permanent part of unobservable skills (e.g., "innate ability"), $\phi_{t}$ is its time-varying price, and $\varepsilon_{i t}$ is the stochastic component due to earnings shocks whose variance is also allowed to change over time. If one is prepared to assume that the distribution of innate ability in the population is invariant, then with the help of panel data one can separate the rise in the return to ability from the increase in the volatility of transitory earnings shocks.

Observation 10 Around one-half of the rise in residual earnings inequality is explained by the permanent components (e.g., a higher return to ability), with the rest accounted for by transitory earnings shocks (Gottschalk and Moffitt 1994). ${ }^{11}$

\footnotetext{
${ }^{9}$ Skilled and unskilled labor are defined as in footnote 7.

${ }^{10}$ Notice that, typically, occupation is excluded from these regressions. Including occupation would reduce the fraction of unexplained wage variance.

${ }^{11}$ Note that a rise in the return on ability does generate an increase in cross-sectional variation of wages because it multiplies individual ability in the log-wage Mincerian equation.
} 
Interestingly, the rise in the transitory component is not due to higher job instability or labor mobility (Neumark, 2000), but rather to more volatile wage dynamics, in particular faster wage growth on the job and more severe wage losses upon displacement (Violante 2002).

In Table 1 we report some key numbers on unemployment, wage inequality, and labor income shares for several OECD countries at five-year intervals from 1965 to 1995. We are particularly interested in the comparison between the United States and continental European countries (averaged in the row labeled Europe Average). For completeness, we include data for the United Kingdom and Canada, whose behavior falls somewhere between that of the United States and continental Europe.

\section{TABLE 1}

Observation 11 The time pattern of wage inequality over the past 30 years differs substantially across countries. The U.K. economy had a rise in wage inequality similar to that in the U.S. economy, except for the fact that the average real wage in the United Kingdom has kept growing (Machin 1996). Continental European countries had virtually no change in wage inequality, whereas over the same period they had large increases in their unemployment rates (roughly, all due to longer unemployment durations) and a sharp fall in the labor income share in GDP. On the contrary, in the United States both the unemployment rate and the labor share have remained relatively constant (Blanchard and Wolfers, 2000).

In 1965 the unemployment rate in virtually every European country was lower than in the United States. Thirty years later, the opposite was true: the U.S. unemployment rate rose only by 1.7 percent from 1965 to 1995, whereas the average unemployment rate increase of European countries was 8.4 percent. $^{12}$

The labor income share has declined only marginally in the United States - by 1.5 percentage points from 1965 to 1995 - while on average it fell by almost 6 points in Europe. Wage inequality, measured by the percentage differential between the ninth and the first earnings deciles for male workers, rose only slightly in Europe by 4 percent in the period from 1980 to 1995, and it even declined in some countries (Belgium, Germany, and Norway). Recall that, over the same period, earnings inequality surged in the United States: the OECD data show a rise of almost 30 percent, close to the numbers we reported earlier in this section.

Interestingly, the European averages hide much less cross-country variation than one would expect, given the raw nature of the comparison. For example, in 11 out of the 14 continental

\footnotetext{
${ }^{12}$ Notice, however, that in the United States non-participation of the low-skilled males rose from 7 percent to 12 percent from the early 1970s to the late 1990s (Juhn, 1992 and Murphy and Topel, 1997).
} 
European countries, the increase in the unemployment rate has been larger than 6 percentage points, and in 9 countries the decline in the labor share has been greater than 5 percentage points.

Recently, Rogerson (2004) has argued that if one focuses on employment rate differences between the United States and Europe rather than on unemployment rate differences, a new set of insights emerges from the data. Employment rates in the United States start to increase relative to European employment rates twenty years before the divergence in unemployment rates. Moreover, the increase in European unemployment rates is correlated with the decline of European manufacturing employment.

\subsection{Technological Change}

The standard measure of aggregate technological change, total factor productivity (TFP), does not distinguish between the different ways in which technology grows. First, technology growth may differ across final-output sectors and second, it may have different effects on the productivity of different input factors. The recent experience of developed countries, however, seems to suggest that in the past 30 years technological change has originated in particular sectors of the economy and has favored particular inputs of production.

Arguably, the advent of microelectronics (i.e., microchips and semiconductors) induced a sequence of innovations in information and communication technologies with two features. First, sector-specific productivity (SSP) growth substantially increased the productivity of the sector that produces new capital equipment, making the use of capital in production relatively less expensive. Second, factor-specific productivity (FSP) growth favored skilled and educated labor disproportionately. In other words, the recent technological revolution has affected the production structure in a rather asymmetric way.

Our assessment of the importance of SSP and FSP changes relies heavily on observed movements in relative prices. For SSP change, we rely on the substantial decline of the price of equipment capital relative to the price of consumption goods, a process that does not show any sign of slowing down. On the contrary, it shows an acceleration in recent years. For FSP change, we rely on the substantial increase in the wage of highly educated workers relative to less educated workers, the skill premium.

We first review the Solow growth accounting methodology for TFP within the context of the one-sector neoclassical growth model and then introduce SSP accounting and how it applies to the idea of capital-embodied technical change. ${ }^{13}$ Next, we discuss how an acceleration of capital-

\footnotetext{
${ }^{13}$ Our presentation is instrumental to the discussion of the impact of technological change on labor markets, and hence it is kept to the bare minimum. Jorgenson's (2004) chapter of this Handbook provides an exhaustive treatment of traditional and modern growth accounting.
} 
embodied technical change might relate to the much-discussed TFP growth slowdown in the "70s and '80s; here, we discuss the possible relevance of the concept of General Purpose Technologies (GPTs). Finally, we explain the mapping between relative wages and FSP changes.

\subsubsection{Total Factor Productivity Accounting}

Standard economic theory views production as a transformation of a collection of inputs into outputs. We are interested in how this production structure is changing over time. At an aggregate National Income and Product Accounts (NIPA) level we deal with some measure of aggregate output, $y$, and two measures of aggregate inputs: capital, $k$, and labor, $l$. The production structure is represented by the production function, $F: y=F(k, l, t)$. Since the production structure may change, the production function is indexed by time, $t$. Aggregate total factor productivity changes when the production function shifts over time, i.e., when there is a change in output which we cannot attribute to changes in inputs. More formally, the marginal change in output is the sum of the marginal changes in inputs, weighted by their marginal contributions to output (marginal products), and the shift of the production function, $\dot{y}=F_{k} \dot{k}+F_{l} \dot{l}+F_{t} .{ }^{14}$ This is usually expressed in terms of growth rates as

$$
\hat{y}=\eta_{k} \hat{k}+\eta_{l} \hat{l}+\hat{A}, \text { with } \hat{A}=F_{t} / F \text {, }
$$

where hats denote percentage growth rates, and the weight on an input growth rate is the elasticity of output with respect to the input: $\eta_{k}=F_{k} k / F$ and $\eta_{l}=F_{l} l / F$. Alternatively, if we know the elasticities, we can derive productivity growth as output growth minus a weighted sum of input growth rates.

Solow's (1957) important insight was that, under two assumptions, we can replace an input's output elasticity - which we do not observe - with the input's share in total revenue, for which we have observations. First, we assume that production is constant returns to scale, i.e., that if we are to double all inputs, then output will double, implying that the output elasticities sum to one: $\eta_{k}+\eta_{n}=1$. Second, we assume that producers act competitively in their output and input markets, i.e., that they take the prices of their products and inputs as given. Profit maximization then implies that inputs are employed until the marginal revenue product of an input is equalized with the price of that input. In turn, this means that the output elasticity of an input is equal to the input's revenue share. For example, for the employment of labor, profit maximization implies that $p_{y} F_{l}=p_{l}$, which can be rewritten as $\eta_{l}=F_{l} l / F=p_{l} l / p_{y} y=\alpha_{l}$ ( $p_{i}$ stands for the price of good $i$ ). With these two assumptions, we can calculate aggregate productivity growth, also known

\footnotetext{
${ }^{14}$ The marginal change of a variable is its instantaneous rate of change over time; that is, if we write the value of a variable at a point in time as $x(t)$, then the marginal change is the time derivative, $\dot{x}(t)=\partial x(t) / \partial t$. Nothing is lost in the following if the reader interprets $\dot{x}(t)$ as the change of a variable from year to year; that is, $x(t)-x(t-1)$.
} 
as total factor productivity (TFP) growth, as

$$
\hat{A}=\hat{y}-\left(1-\alpha_{l}\right) \hat{k}-\alpha_{l} \hat{l} .
$$

The Solow growth accounting procedure has the advantage that its implementation does not require very stringent assumptions with respect to the production structure, except constant returns to scale, and it does not require any information beyond measures of aggregate output and input quantities and the real wage. This relatively low information requirement comes at a cost: this aggregate TFP measure does not provide any information on the specific sources or nature of technological change.

Given available data on quantities and prices for industry outputs and inputs, it is straightforward to apply the Solow growth accounting procedure and obtain measures of sector-specific technical change (see, for example, Jorgenson et al., 1987). Recently Jorgenson and Stiroh (2000) have documented the substantial differences in output and TFP growth rates across U.S. industries over the period 1958-1996. In particular, they point out that TFP growth rates in high-tech industries producing equipment investment are about three to four times as high as a measure of aggregate TFP growth. Also based on industry data, Oliner and Sichel (2000) and Jorgenson (2001) attribute a substantial part of the increase of aggregate TFP growth over the second half of the 1990s to one industry: semi-conductors.

\subsubsection{Sector-Specific Productivity Accounting}

The convincing evidence for persistent differences of SSP growth raises the potential of serious aggregation problems for the analysis of aggregate outcomes. We now discuss SSP accounting in a simple two-sector growth model that focuses on the distinction between investment and consumption goods. This approach provides a straightforward measure of SSP growth, and it keeps the aggregation problems manageable. Based on this approach, we present evidence of substantial increases of the relative productivity in the equipment-investment goods producing industries and stagnant productivity in the consumption goods industries since the mid 1970s.

Greenwood et al. (1997) use a two-sector model of the economy-where one sector produces consumption goods and the other new capital - to measure the relative importance of total-factor productivity changes in each of these sectors. Goods - consumption, $c$ and new capital, $x$-are produced using capital and labor as inputs to constant-returns-to-scale technologies,

$$
c=A_{c} F\left(k_{c}, l_{c}\right) \text { and } x=A_{x} F\left(k_{x}, l_{x}\right)
$$

and total factor inputs can be freely allocated across sectors,

$$
k_{c}+k_{x}=k \text { and } l_{c}+l_{x}=l .
$$


Note that we have assumed that factor substitution properties are the same in the two sectors; that is, the functions relating inputs to outputs are the same. One can show that with identical factor substitution properties, the two-sector economy is equivalent to a one-sector economy with exogenous changes in the relative price of investment goods, $1 / q$

$$
y=c+x / q=A_{c} F(k, l) .
$$

In particular, the relative price of investment goods is the inverse of the relative productivity advantage of producing new capital goods: $:^{15}$

$$
q=A_{x} / A_{c}
$$

The relative productivity of the investment goods sector is also called "capital-embodied" technical change, because $q$ can be interpreted as the productivity level (quality) embodied in new vintages of capital. ${ }^{16}$

Accounting for quality improvements in new products is a basic problem of growth accounting. ${ }^{17}$ This is especially true for our framework since we measure investment in terms of constant-quality capital goods. In a monumental study, Gordon (1990) constructed quality-adjusted price indexes for different types of producers' durable equipment. Building on Gordon's work, Hulten (1992), Greenwood et al. (1997), and Cummins and Violante (2002) have derived aggregate time series for capital-embodied technical change in the U.S. economy. ${ }^{18}$ They use the property just described: that the constant-quality price of investment relative to consumption (precisely, nondurable consumption and services) reveals the extent of productivity improvements. Their main finding is that:

Observation 12 Productivity growth in the sector producing equipment investment has accelerated relative to the rest of the economy since the early to mid-1970s.

\footnotetext{
${ }^{15}$ Jorgenson (2004), in this handbook, labels this methodology, where relative productivity growth is measured off the decline in relative prices, the "price approach" to growth accounting.

${ }^{16}$ Define investments in consumption units as $i=x / q$. Then, the aggregate resource constraint reads

$$
c+i=A_{c} F(k, l)
$$

and the law of motion for capital in efficiency units is $k^{\prime}=(1-\delta) k+i q$.

${ }^{17}$ See this Handbook's chapter by Bils and Klenow (2004) on the measurement of quality for an overview of the different approaches.

${ }^{18}$ Hulten's series strictly uses Gordon's data and therefore spans until 1983. Greenwood et al. extend Gordon's index to 1992 by applying a constant adjustment factor to the National Income and Product Accounts (NIPA) official price index. Cummins and Violante update the series to 2000. Starting with Gordon's quality-adjusted price indexes for a variety of equipment goods from 1947 to 1983, they estimate the quality bias implicit in the NIPA price indexes for that period. Using the official NIPA series, they then extrapolate the quality bias from 1984 to 2000 for each equipment type and aggregate into an index for equipment and structure.
} 
The solid line in Figure 2 shows the relative productivity of the equipment investment goods sector, $q$, for the period 1947-2000, normalized to 1 in the first year. This index grows at an annual rate of about 1.6 percent until 1975 and at an annual rate of 3.6 percent thereafter. In the 1990s, productivity growth embodied in capital has been spectacularly high, reaching an average annual rate just below 5 percent.

\section{FIGURE 2}

The measurement of SSP growth through changes in relative prices requires that the price measures used are appropriately adjusted for quality improvements, presenting a problem for the time period studied since, arguably, the IT revolution has caused large improvements in the quality of durable goods and has led to the introduction of a vast range of new items. Therefore, alternative ways of measuring capital-embodied productivity advancements have been proposed. Hobijn (2000) calculates the rate of embodied technical change by calibrating a vintage capital model. His findings are very similar to the price-based approach, both in terms of the average growth rate, and in terms of the timing of the technological acceleration. Bahk and Gort (1993) and Sakellaris and Wilson (2004) use plant-level data to estimate production functions and assess the productivity effects of new investments. They estimate the growth rate of capital-embodied technical change to be between 12 and 18 percent per year, much higher than the rest of the literature.

We calculate the rate of SSP change in the consumption goods sector based on the standard Solow approach. It is well known that the U.S. labor income share in GDP has been remarkably stable for the time period considered. We therefore choose a Cobb-Douglas parametric representation of the production function,

$$
y=A_{c} k^{\alpha} l^{1-\alpha},
$$

with labor income share, $1-\alpha=0.64$ (Cooley and Prescott 1995). Conditional on observations for real GDP (in terms of consumption goods), the real capital stock, and employment, we can use this expression to solve for the SSP of the consumption sector $A_{c} \cdot{ }^{19}$ The common finding from this computation, as evident from the dashed line in Figure 2, is

Observation 13 Productivity in the sector producing consumption goods (precisely, nondurable and services) shows essentially no growth over the two decades 1975-1995.

\footnotetext{
${ }^{19}$ It is important to adjust the capital and labor input measure for quality change. As pointed out above, quality adjustment of investment is useful so as to capture investment-specific technical change. The capital stock is then calculated as the cumulative sum of past undepreciated constant-quality investment. From our discussion of wage inequality it follows that the labor input needs to be adjusted for two reasons. First, the skill premium has been increasing since the mid-1970s, and thus the productivity of skilled labor, $A_{s}$, is increasing faster than the productivity of unskilled labor, $A_{u}$. Second, at the same time, the relative supply of skilled labor has been increasing, inducing large changes in the composition of the stock of labor. To account for quality changes, we use the labor input index computed by Ho and Jorgenson (1999). The dotted line in Figure 2 plots this quality index for labor which grows at an average rate of $0.8 \%$ per year.
} 
The approach of Greenwood et al. (1997) defines aggregate output in terms of consumption goods. This is rather non-standard. The usual approach, especially as applied to the study of SSP, defines aggregate output growth as a revenue-weighted sum of sectoral output growth rates: a Divisia index (see, e.g., Jorgenson 2001, or Oliner and Sichel 2000). For this more standard approach, one can write aggregate TFP growth as the revenue-weighted sum of sectoral TFP growth. While the Divisia-aggregator approach is a definition with some desirable properties, the Greenwood et al. (1997) approach is based on a particular theory and requires certain identifying restrictions concerning the production structure. Hall (1973) shows that in multi-sector models a unique output aggregator, that is, a function that relates some measure of aggregate output to some measure of aggregate input, exists if certain separability conditions for the aggregate production possibility frontier are satisfied. The conditions for such an output aggregator to exist are, essentially, the ones imposed by Greenwood et al. (1997). ${ }^{20}$ Given the definition of aggregate output in equation (6), SSP for consumption, or $A_{c}$, is then sometimes interpreted as neutral, or disembodied, aggregate technological change.

\subsubsection{Reconciling the Acceleration in Investment-Specific Productivity Growth with the Slowdown in TFP: General Purpose Technology and Learning}

The stagnation of aggregate TFP since the mid-1970s - evident from Figure 2-accounts for the phenomenon often referred to as a "productivity slowdown" in the growth accounting literature. ${ }^{21}$ How can we reconcile the acceleration of investment SSP with a slowdown of consumption SSP? One interpretation builds on learning-by-doing (LBD). New investment goods do not attain their full potential as soon as they are introduced but, rather, their productivity can stay temporarily below the productivity of older capital that was introduced same time ago. This feature is attributed to learning effects. ${ }^{22}$

These learning effects can be extremely important when the technological change is "drastic." Recent discussions suggest that the advent of microelectronics led to a radical shift in the technological paradigm, i.e., to a new "general purpose technology" (GPT). Bresnahan and Trajtenberg (1995) coined this term to describe certain major innovations that have the potential for pervasive use and application in a wide range of sectors of the economy. David (1990) and Lipsey et al. (1998) cite the microchip as the last example of such innovations that included, in ancient times, writing

\footnotetext{
${ }^{20}$ For further details on this issue, see Hornstein and Krusell (2000).

${ }^{21}$ Since non-equipment investment represents more than three-fourths of GDP, the slowdown of consumption SSP change accounts for most of the slowdown of aggregate TFP change.

${ }^{22}$ The literature on learning effects is large. Lucas (1993) discusses the classic example of LBD related to the construction of the liberty ships of World War II. Bahk and Gort (1993) measure substantial LBD effects at the plant level. Irwin and Klenow (1994) present evidence of LBD in the production of semiconductors. Jovanovic and Nyarko (1995) document learning curves in several professions. Huggett and Ospina (2001) find evidence that the effect of a large equipment purchase is initially to reduce plant-level total factor productivity growth.
} 
and printing and, in more recent times, the steam-engine and the electric dynamo. ${ }^{23}$ Although it is hard to define the concept satisfactorily, given available data, we list as a "fact" the dominant view, which maintains that:

Observation 14 Technological change in the past 30 years displays a "general purpose" nature.

Though most of the evidence supporting this statement is anecdotal, there are some bits of hard evidence. Hornstein and Krusell (1996) document that the decline in TFP occurred roughly simultaneously across many developed countries. More recently, Cummins and Violante (2002) construct measures of productivity improvements for 26 different types of equipment goods. Using the sectoral input-output tables, they aggregate these indexes into 62 industry-level measures of equipment-embodied technical change, and document that their growth rate has accelerated by a similar amount in virtually every industry in the 1990s. Jovanovic and Rousseau (2004a) draw an articulated parallel between the diffusion of electricity in the early 20th century and the diffusion of information technologies (IT) eighty years later based on a variety of data. Their evidence supports the view that both episodes marked a drastic discontinuity in the historical process of technological change. Taken together, all these observations suggest that, similar to other past GPTs, IT has affected productivity in a general way over the past three decades.

There are two versions of the argument that IT are responsible for the observed productivity slowdown. According to one, the slowdown is real: when learning-by-doing is important in improving the efficiency of a production technique, abandoning the older, but extensively used technology to embrace a new method of production involves a "step in the dark" that can lead to a temporary slowdown in labor productivity (Hornstein and Krusell, 1996, Greenwood and Yorukoglu, 1997, and Aghion and Howitt, 1998, chapter 8).

An alternative, complementary version maintains that the slowdown is a statistical artifact due to mismeasurement: if the phase of IT adoption coincides with associated investments in organizational or intangible capital, as our Section 4 will suggest, then insofar as these investments are not included in the official statistics, measured TFP growth will first underestimate and then overestimate "true" TFP growth (Hall, 2001, and Basu et al. 2003). The reason is that initially, when large investments in organizational capital are made, the "output side" of the mismeasurement is severe. Later, when the economy has built a significant stock of organizational capital, the "input side" of mismeasurement becomes dominant.

This explanation of the TFP slowdown is appealing, but extremely difficult to evaluate quantitatively because of the lack of direct evidence on how organizations learn. Using some theory,

\footnotetext{
${ }^{23}$ Gordon (2000) offers a dissenting view on the issue of whether or not information technologies measure up to the great inventions of the past. In his view, the aggregate productivity impact of computers and telecommunications equipment has been fairly small compared to, say, the telegraph, the railroad, or electricity.
} 
Hornstein (1999) argues that one key parameter is the fraction of knowledge that firms can transfer from the old to the new technology but also shows that the model's predictions vary significantly across plausible parameterizations. Atkeson and Kehoe (2002) build an equilibrium model to measure the dynamics of organizational capital during the "electrification of America". They criticize the Bahk and Gort (1993) view that organizational learning is reflected into an increase in the productivity of labor at the plant level: in an equilibrium model where labor is mobile, productivity is equalized across plants. Instead, they argue that when organizations learn they expand in size. Thus, cross-sectional microdata on the size distribution of plants allows to identify the structural parameters of the stochastic process behind organizational learning.

Finally, Manuelli (2000) argues that, even in absence of learning effects, the anticipation of a future technological shock embodied in capital can result in a transitional phase of slowdown of economic activity. In the period between the announcement and the actual availability of the new technology, the existing firms prefer exercising the option of waiting to invest and the new firms prefer delay entering. Consequently, output falls temporarily until the arrival of the new technology. ${ }^{24}$

\subsubsection{Factor-Specific Productivity Accounting}

In order to talk about changes in FSP, one possibility is to generalize the production function in equation (8) by disaggregating the contributions to production of the two labor inputs - skilled (e.g., more educated) and unskilled (e.g., less educated) labor. Suppose the aggregate labor input, $l$, is a CES function of skilled and unskilled labor, $l_{s}$ and $l_{u}$, with FSPs $A_{s}$ and $A_{u}$ :

$$
l=\left[\left(A_{s} l_{s}\right)^{\sigma}+\left(A_{u} l_{u}\right)^{\sigma}\right]^{1 / \sigma}, \sigma \leq 1
$$

Relative wage data can then be employed to understand the nature and evolution of FSP in the economy. With competitive input markets, the relative wages are a function of the relative FSP and the relative labor supply:

$$
\ln \left(\frac{w_{s}}{w_{u}}\right)=\sigma \ln \left(\frac{A_{s}}{A_{u}}\right)-(1-\sigma) \ln \left(\frac{l_{s}}{l_{u}}\right) .
$$

The elasticity of substitution between skilled and unskilled labor here is $1 /(1-\sigma)$. Katz and Murphy (1992) run a simple regression of relative wages on relative input quantities and a time trend to capture growth in the ratio $\frac{A_{s}}{A_{u}}$. They measure skilled labor input as total hours supplied to the market by workers with at least a college degree. Their estimate of the substitution elasticityaround 1.4 (or $\sigma=0.29$ ) -indicates that a ten-percent increase in the relative supply of skilled

\footnotetext{
${ }^{24}$ We refer the reader to Hornstein and Krusell (1996) for a list of alternative explanations of the TFP slowdown that are not based on changes in technology.
} 
labor implies a seven percent decline of the skill premium. ${ }^{25}$ The estimated elasticity of substitution between factors, together with the growing skill premium, imply an increase in the relative FSP of skilled labor in excess of 11 percent per year. We conclude that the typical result of similar exercises on U.S. data is that:

Observation 15 Recent technological advancements have been favorable to the most skilled workers in the population. In other words, technical change has been skill-biased.

The "acceleration" in the rate of capital-embodied technical change, the "general purpose" nature of the new wave of technologies, and the "skill-biased" attribute of the recent productivity advancements are the three chief features of the new technological environment that seems to have emerged since the early to mid 1970s. The various economic theories that we are about to review in the rest of this chapter are built on various combinations of these features.

\section{Skill-Biased Technical Change: Inside the Black Box}

As we have just observed, the pattern of relative quantities of skills measured by education suggest that the behavior of the skill premium, that is, the increase in the wages of highly educated workers relative to those of less educated workers, should be attributed to a skill-biased labor demand shift, or to "skill-biased technical change." In the absence of a factor-bias in technological progress, the upward trend in the supply of skills documented in Figure 1 (top panel) would have reduced the skill premium.

Katz and Murphy (1992) were the first to use a production framework with limited substitution between skilled and unskilled labor to recover changes in relative FSP from changes in the skill premium. One should note a substantial drawback of the pure skill-biased technical change hypothesis: it is based on unobservables (relative FSP changes) that are measured residually from equation (10), so very much like TFP, it is a "black box". In this section we review the attempts to give some specific economic content to the notion of skill-biased technical change. Krusell et al. (2000; KORV henceforth) argue that the dynamics of SSP that induced the substantial drop in the relative price of equipment capital is the force behind the rise in the skill premium.

\subsection{A Historical Perspective on the Skill Premium}

In Section 2 we have observed that, over the last 100 years, wage inequality first declined and then increased, with the turning point somewhere around 1950. Can the theoretical models developed

\footnotetext{
${ }^{25}$ The estimated input elasticity of about 1.4 is consistent with a large empirical literature on factor substitution that uses a wide array of data sets (time series as well as cross-section) and methods; see, e.g., Hamermesh (1993).
} 
to interpret the increasing wage inequality for the second half of the 20 th century also account for the declining wage inequality of the first half of the 20th century?

\subsubsection{Capital-Skill Complementarity}

Figure 4 plots the relative price of equipment together with the returns to one year of education (both college and high school) since 1929. ${ }^{26}$ The pattern is rather striking and is broadly consistent with an explanation based on the capital-skill complementarity hypothesis. During the first half of the century, the price of capital increased which slowed the demand for educated labor and the skill premium. Then around mid-century it started to decline, fostering a strong demand shift in favor of educated labor.

\section{FIGURE 4}

This extension of the KORV analysis to the whole 20 th century is yet to be performed formally. ${ }^{27}$ Thus, before one fully subscribes to this explanation, it is worth discussing the key assumption behind the model. Is it an accurate historical assessment that the introduction of new capital goods has systematically increased the productivity of skilled labor relative to the productivity of unskilled labor? In other words, when can one date the birth of work organizations displaying capital-skill complementarity?

According to Goldin and Katz (1998), until the early 20th century there was no trace of skillbiased technical change; rather, the opposite bias was at work. The origins of capital-skill complementarity are associated with the introduction of electric motors, and a shift away from assembly lines and toward continuous and batch processes. This development started in the second and third decades of the 20th century. In particular, the declining relative price of electricity, and the consequent electrification of factories, made it possible to run equipment at a higher speed. This, in turn, increased the demand for skilled workers for maintenance purposes. Since then, the introduction of new equipment, such as numerically controlled machines, robotized assembly lines, and finally computers further increased the relative productivity of skilled labor. Thus, we conclude that based on anecdotal evidence, the period portrayed in Figure 4 is one where capital-skill complementarity became more important.

\footnotetext{
${ }^{26}$ The relative price is computed from series available on the BEA website. In particular, compared to the series discussed previously in the chapter, there are no quality adjustments. As a result, the acceleration which occurred since the mid 1970s is less evident here. The series on the return to education for 1939, 1949, 1959, 1969, 1979, 1989, and 1995 are taken from Table 7 in Goldin and Katz (1999) and interpolated linearly for the missing years in between. The first datapoint for 1929 is obtained by linear interpolation from 1914 .

${ }^{27}$ Admittedly, the evidence in Figure 4 is rather indirect. Looking directly at the stock of equipment (unadjusted for quality improvements), its average annual growth rate in the periods 1930-1950, 1950-1980, 1980-2000 is, respectively, $2.2 \%, 5.0 \%$ and $4.2 \%$. However, when quality-adjusted, the growth rate of equipment from 1980-2000 is close to $8 \%$ (Cummins and Violante, 2002). See also Hornstein (2004) for a discussion of historical trends of U.S. capital-output ratios.
} 
Mitchell (2001), in a related interpretation on the last century of data, emphasizes the technological aspects of optimal plant size. Mitchell documents a striking similarity between the historical path of wage inequality and the pattern of average plant size in manufacturing which rose over the 1900-1950 period and shrunk between 1950 and 2000, thus almost producing the mirror image of inequality at low frequencies. The time-path of plant size can be interpreted as an indicator of the magnitude of the fixed costs of capital and fits well with the evidence of Figure 4.

In Mitchell's model, production requires performing a large set of tasks with capital and two types of labor, skilled and unskilled. Entrepreneurs face a fixed cost to operate capital, skilled labor, and unskilled labor. Unskilled labor has a higher fixed cost and a lower variable cost than does skilled labor; e.g., unskilled labor is specialized and needs a certain amount of training to perform all the tasks, whereas skilled labor is naturally able in multi-tasking. ${ }^{28}$

The move from craft shops to assembly lines (1900-1950) induced a rise in the fixed cost: the optimal size of the plant rose and with a larger size, plants optimally employed more unskilled workers with large fixed cost, but low variable cost (wages). The demand for unskilled workers rose, weakening the skill premium. As an illustration of the importance of fixed costs for this type of production method, recall that all Ford plants had to be closed and redesigned when the "Model T" was discontinued (Milgrom and Roberts, 1990).

The shift toward more flexible, numerically controlled machines and IT capital (1950-2000) led firms to adopt a smaller scale of production and employ more highly skilled workers whose low fixed cost makes them preferable to unskilled workers in small plants. The increased demand for skilled labor thus raised the skill premium. Based on a calibration exercise, the model can account for two thirds of the movements in the skill premium. ${ }^{29}$

\subsubsection{Directed Technical Change}

The theory of directed technical change maintains that a growth in the relative supply of a factor of production should induce technical change biased in favor of that factor. Historically, there are two important episodes of largely "exogenous" spurs in relative factor supply.

First, there was an increase in the supply of unskilled labor in urban areas of England during the 19th century. A careful look at the nature of technological progress over this period supports the theory. Goldin and Katz (1998) argue that in the 19th century the wave of technological innovations

\footnotetext{
${ }^{28}$ This idea is further developed in Holmes and Mitchell (2004). This paper develops a theory of the intrinsic difference between three key factors of production: capital, unskilled labor, and skilled labor. Based on this theory, the authors develop implications for: 1) how capital and skill intensity vary as a function of size of plants, 2) the micro-foundations of capital-skill complementarity, 3) the effect of trade on the skill premium and the historical relationship between the plant size-skill correlation and the skill-premium.

${ }^{29}$ Note that this model implies that the origin of capital-skill complementarity is to be located only around 1950 , later than what was argued in Goldin and Katz (1998).
} 
substituted physical capital and raw labor for skilled artisan workers (Braverman, 1974 and Cain and Paterson, 1986). For example, automobile production began in artisanal shops where the car was assembled from start to finish by a small group of "all-around mechanics." Only a few decades later, the Tayloristic model of manufacturing would bring together scores of unskilled workers in large-scale plants to assemble completely standardized parts in a fixed sequence of steps for mass production.

Second, there was a surge in skilled labor (i.e., workers with literacy and numerical skills) due to the "high-school movement" of 1910-1940. As pointed out by Aghion (2002), with respect to this episode, the theory finds weaker support. On the one hand, as we discussed earlier, it appears that the first part of the 20th century indeed marked the beginning of a transformation in production methods biased towards skilled labor (from assembly lines to continuous and batch production processes). On the other hand, there was a decline in the returns to high school and the returns to college were stable (see Figure 4). Why is it that this wave of skill-biased technical change, which was as strong as the one 50 years later, did not have a similar impact on the wage structure? This question remains unanswered to date. ${ }^{30}$

\section{Inside the Firm: the Organization of Work}

Hayek (1945) argued that a fundamental problem of societies is how to use optimally the knowledge that is available, but is dispersed across individuals. In frictionless markets, prices can solve this problem: they transmit knowledge about relative scarcity and relative productivity of resources. Since Coase (1937), it is well understood that frictions limit the efficiency of markets, and they divert certain transactions to occur within the boundaries of firms. Within the firm, the organization of work and production plays the role of the market as "information processor" to allow efficient use and transmission of knowledge.

It is therefore not surprising that the recent innovations that revolutionized the way in which information and communication takes place have affected the workplace organization within firms and the boundaries of firms. Their impact on the wage structure is perhaps less clear. The maintained hypothesis in the literature is that the recent episodes of reorganization of production, especially in manufacturing, have favored adaptable workers who have general skills and who are more versed at multi-tasking activities. An alternative view, which we will develop later in this section, is that organizational change is not induced by technological change, but that the increased relative supply of skilled labor created the incentives to change the organization of production.

\footnotetext{
${ }^{30}$ Institutions might have played a role in the 1940s. Goldin and Margo (1992) argue that the National War Labor Board operated an explicit policy of wage compression during that period.
} 


\subsection{The Milgrom-Roberts Hypothesis: IT-Driven Organizational Change}

Milgrom and Roberts (1990) were the first to emphasize the interaction between the diffusion of information technologies in the workplace and the reorganization of production. Their hypothesis builds on the idea that information technologies reduce a set of costs within the firm which triggers the shift towards a new organizational design. First, electronic data transmission through networks of computers reduces the cost of collecting and communicating data, and computer-aided design and manufacturing reduces the costs of product design and development. Second, there are complementarities among a wide group of strongly integrated activities within the firm (product design, marketing, and production), and pronounced non-convexities and indivisibilities in each activity.

As a result, as the marginal cost of IT declines, it is optimal to reorganize all activities to exploit this shock, and, due to non-convexities, organizational change can be sudden and drastic in nature. In particular, because of lower communication costs the layers in the hierarchical structure can be reduced, so that the organization of the firm becomes "flatter." ${ }^{1}$ Workers no longer perform routinized, specialized tasks, but they are now responsible for a wide range of tasks within teams. These teams, in turn, communicate directly with managers. Because of the flexibility of IT capital, the scale of production decreases (recall the evidence in Mitchell (2001) on plant size), allowing greater production flexibility and product customization.

An elegant formalization of this hypothesis is contained in Bolton and Dewatripont (1994). They study the optimal hierarchical structure for an organization whose only objective is that of efficiently processing a continuous flow of information and show using their model that a reduction in communication costs leads to a flatter and smaller organization.

\subsubsection{Implications for the Wage Structure}

Although in their original papers neither Milgrom and Roberts nor Bolton and Dewatripont explore the implications of organizational change for the wage structure, a small but growing literature on IT-driven organizational change and inequality has developed since.

Lindbeck and Snower (1996) emphasize the "complementarity" aspect of the Milgrom-Roberts hypothesis. They consider a production function with two tasks and two types of workers. The Tayloristic model would assign one type of workers to each task, according to comparative advantages to exploit specialization. The alternative organization of production is the flexible model, where each type of worker performs both tasks. This more flexible organization is preferred when there are large informational complementarities across tasks. The introduction of IT capital am-

\footnotetext{
${ }^{31}$ Rajan and Wulf (2003) use detailed data on job descriptions in over 300 large U.S. companies to document that the number of layers between the lowest manager and the CEO has gone down over time, i.e., organizations have become "flatter".
} 
plifies these informational complementarities and makes the flexible organization more profitable. Moreover, firms increase the demand for skilled workers who are more adaptable and versed in multi-tasking, and the skill premium rises.

Möbius (2000) focuses on the "customization" aspect of organizational change. When products are standardized, demand is certain and production tasks perfectly predictable, inducing a high division of labor (the Tayloristic principle). New flexible capital allows firms to greatly expand the degree of product variety and customization in product markets. Larger variety implies a more uncertain demand mix because producers become subject to unpredictable "fad shocks" and producers therefore favor a flexible organization of production, with less division of labor. Once again, to the extent that the most skilled workers are also the most adaptable and versatile, the skill premium will increase.

The mechanism in Garicano and Rossi-Hansberg (2003) is based, instead, on the fall in the communication cost within the organization. Their paper has the particular merit of taking the literature on the internal organization of firms (e.g., Bolton and Dewatripont 1994) one step further by recognizing that organizational hierarchies and labor market outcomes are determined simultaneously in equilibrium. Consider an organization where managers perform the most difficult and productive tasks and workers specialize in a set of simpler tasks. Managers also spend a fraction of their time "helping" workers unable to perform their task, and by so doing, they divert resources away from their most productive activities. The fall in the cost of communication allows workers to perform a wider range of tasks, using a smaller amount of the manager's time. The implications for wage inequality are stark. First of all, since workers are heterogeneous in ability, and ability is complementary to the number of tasks performed, inequality among workers within the firm increases. Second, the pay of the manager relative to that of the workers rises because the manager can concentrate on the tasks with high return.

The previous papers have studied how IT-based advances have affected the organizational structure within firms. Saint-Paul (2001) addresses the spectacular rise in the pay of CEOs and a few other professions (e.g., sportsmen and performers) documented in Section 2 using a model where IT-based advances affect the organization of markets with frictions. Saint-Paul combines a model with "superstar" or "winner-take-all" effects (Rosen 1981) with the advent of information technology. In his model, human capital has two dimensions: productivity, i.e., the ability to produce units of output, and creativity, i.e., the ability to generate ideas that can spread (and generate return) over a segment of an economy, called a "network." The diffusion of information technology expands networks increasing the payoff to the most creative workers and widening the income distribution at the top. However, as networks become large enough, the probability that within the same network there will be somebody with another idea at least as good rises: superstars end up 
competing against each other, mitigating the inegalitarian effects of information technology. Under certain parametric assumptions, inequality first rises and then falls over time.

\subsubsection{Empirical Evidence on the Complementarity between Technology, Organiza- tional Change and Human Capital}

Bresnahan et al. (2002) investigate the hypothesis that IT adoption, workplace reorganization, and product variety expansion (customization) are complementary at the firm level. Their view is that simply installing computers or communications equipment is not sufficient for achieving efficiency gains. Instead, firms must go through a process of organizational redesign. The combination of IT investments and reorganization represents a skill-biased force increasing the relative demand for more educated labor.

Their empirical analysis is based on a sample of over 300 large firms in the United States, and their definition of organizational change is a shift towards more decentralized decision making and more frequent teamwork. They find a significant correlation between IT, reorganization, and various measures of human capital. ${ }^{32}$

In a related paper, Caroli and Van Reenen (2001) argue that the existence of complementarities between organizational change and the demand for skilled labor leads to three predictions: 1) organizational change should be followed by a declining demand for less skilled workers; 2) in the vein of the directed technical change hypothesis (see next section), cheaper skilled labor should increase the occurrence of organizational change; and 3) organizational change should have a larger impact in workplaces with higher skill levels.

They test these predictions combining two data sets, one for Britain and one for France, with information on changes in work organization, working practices, and the skill level of the labor force. Interestingly, they also have information on the introduction of new IT capital, so they can distinguish the effect of organizational change from that of skill-biased technical progress. They find some supporting evidence for all three predictions.

Baker and Hubbard (2003) offer an example where technological change not only affects the organizational design of firms but also the boundary of firms. In particular, they study how IT may have reduced the moral hazard problem in the U.S. trucking industry. Drivers may simply operate the trucks as employees of the dispatching company, or they may actually own the trucks they operate. If the dispatcher owns the truck, there is only limited assurance that the driver will operate in a way that preserves the value of the asset, since the dispatcher cannot perfectly monitor the driving operations. When this moral hazard problem is severe, decentralized ownership will

\footnotetext{
${ }^{32}$ See Brynjolfsson and Hitt (2000) for a survey on the empirical work documenting the causal link from adoption of information technology and organizational transformation within the firm.
} 
be the outcome, that is, the driver owns the truck. Using detailed truck-level data, Baker and Hubbard show that with the introduction of a new monitoring technology-on-board computers linked to the company servers - the share of driver-ownership decreased significantly.

\section{Technical Progress as a Source of Change in Labor Market In- stitutions}

Throughout the chapter, up to this point, we have maintained a "competitive" view of the labor market and argued that skills are priced at their marginal product, potentially explaining large parts of the observed dynamics of inequality. However, the labor market displays very peculiar features compared to many other markets in the economy: a sizeable fraction of labor may be considered as under-employed in any given period (unemployment), individual workers often organize themselves into coalitions (unions), and wages frequently seem to be set through some explicit negotiation between firms and workers (individual and collective bargaining). These attributes of the labor market are, arguably, better captured by non-competitive models. We begin our departure from the purely competitive framework by introducing unions and collective bargaining. Next, we explicitly consider the primitives that lead to frictions in the form of a role for bilateral negotiations.

Historically, unions and centralized bargaining have been key institutions in the determination of wages and other important labor market outcomes. Over the past 30 years, the economies of the United States and the United Kingdom experienced rapid deunionization. In the United States, in the late 1970s, 30 percent of male non-agricultural private-sector workers were unionized. By 2000, only 14 percent were unionized (Farber and Western, 2000). In the United Kingdom, union density among male workers was around 58 percent in the late 1970s and it has fallen uninterruptedly since to 30 percent today (Machin, 2000 and 2003). There is a variety of evidence that unions compress the structure of wages, even after controlling for workers' characteristics, and thus many economists suspect that their decline may have been an important factor in the increase in inequality in the Anglo-Saxon economies (see, e.g., Gosling and Machin, 1995, and DiNardo et al. 1996).

The existing literature has explored mainly two explanations for the decline in unions. The first generation of papers argued that an important force in the fall of unionization is the change in the composition of the economy away from industries, demographic groups, and occupations where union organization was comparatively cheaper and unions have been traditionally strong (Dickens and Leonard, 1985). However, Farber and Krueger (1992) estimate that compositional shifts can account for at most 25 percent of the decline in the United States and have played virtually no role

since the 1980s. Machin (2003) reports that only around 20 percent of the U.K. union decline of the last two decades can be attributed to compositional change. 
The second hypothesis is that the legal and political framework supporting union membership deteriorated in the 1970s and 1980s. ${ }^{33}$ To date, this explanation seems to have gained rather broad acceptance. However, the recent literature has demonstrated that this view has limits as well: the fall in union organizing activity precedes two key political events: the air-traffic controller strike of 1981 and Reagan's Labor Board appointments in 1983 (Farber and Western 2002). U.K. data also show that the fall in union membership pre-dates the first Thatcher government. Overall, we think that the forces behind rapid deunionization are not yet well understood.

In most of continental Europe, unions are still strong, and there are no clear signs of decline in union coverage, but a marked change in union behavior has occurred over the past 30 years. Several indexes of coordination and centralization in unions' bargaining for Europe show a distinct trend towards more decentralized wage negotiations, especially in the Scandinavian countries, whose unionization rates are the highest (Iversen, 1998).

The standard explanation for the shift towards decentralized bargaining is based on the interaction between monetary policy and wage setting arrangements. With an independent national central bank, coordination in bargaining among unions is useful because it allows unions to internalize the implications of their wage claims on inflation. With the advent of the European monetary union and the institution of the European Central Bank within-country coordination proves less useful. However, the evidence in favor of this hypothesis is scant. First, monetary policy does not seem to Granger-cause centralization empirically (Bleaney, 1996). Second, we did not observe a substantial trend towards cross-border coordination in unions' bargaining.

Recently, a new hypothesis for deunionization and decentralization in unions' wage setting, based on skill-biased technological change, has been advanced by Acemoglu et al. (2001) and Ortigueira (2002). Their arguments rest on the view that unions are coalitions of heterogeneous workers which extract rents from employers and only exist insofar as members have an incentive to stay in the coalition and continue bargaining in a centralized fashion. The conjecture of these authors is that skill-biased technical change can dramatically alter such incentives.

\subsection{Skill-Biased Technology and the Fall in Centralized Bargaining}

In many European countries - in particular among the Scandinavian countries - the so-called "Ghent system" creates a fiscal-policy link among unions. Under this system, unemployment benefits are administered by the individual unions, but they are funded by the government through aggregate labor income taxation. Hence, not only does the net income of unions' members depend on their negotiated wage, but, through the equilibrium tax rate, also on the wage claims of other unions.

\footnotetext{
${ }^{33}$ Some authors emphasized anti-union management practices (Freeman 1988). Others focused on changes in the composition of the National Labor Relation Board (Levy, 1985).
} 
Ortigueira (2002) outlines a model economy with this institutional feature, where there are two types of workers, skilled and unskilled, and two unions that can choose to coordinate their wage determination. Unemployment is generated through a frictional labor market with a standard matching function.

Under decentralized bargaining, unions take the tax as given. Ortigueira (2002) shows that there are two possible steady states: in one, unions expect a low tax, thus making moderate wage claims which, in turn, keep equilibrium unemployment and tax rate low, fulfilling the initial expectation; in the other steady state, unions expect a high tax rate, thus making strong wage claims that produce high unemployment and a high tax rate. This second equilibrium yields lower income and lower welfare for union members. Centralized bargaining avoids the coordination failure and the associated welfare losses that can arise in this "bad equilibrium," and hence it can be preferred by unions. Note, however, that the "good equilibrium" under decentralized bargaining is still the best outcome. It is the ex-ante uncertainty that the bad equilibrium could arise that makes coordination attractive.

However, consider what happens with the advent of a skill-biased technology that increases the demand for skilled workers sharply, reducing their unemployment incidence. When unemployment benefits are proportional to wages, the fact that skilled workers are much less likely to be unemployed decreases the social expenditures of the government. As a result, under decentralized bargaining, the equilibrium with high taxes and low welfare does not survive the advent of a skill-biased technology. This justifies the shift in unions' wage setting policies towards decentralization. ${ }^{34}$

\subsection{Discussion}

The testable implications that can be identified above are that (1) among the experienced workers, the most skilled leave the unions in response to technological improvements and that (2) among the new entrant cohorts, the most educated workers opt for non-unionized jobs. However, these implications are derived from theories of technology-induced deunionization that are rather exploratory; more sophisticated and rigorous models of unions (with endogenous membership and endogenous wage-compression mechanisms) are yet to be developed.

The recent empirical studies by Card (2001), for the United States, and Addison et al. (2004), for the United Kingdom, compare the unionization rate across several skill groups before and after the collapse in union density in these two countries (1973 and 1993 for the United States, and 1983 and 1995 for the United Kingdom). The common finding of these two papers, is that unionization

\footnotetext{
${ }^{34}$ See also den Haan (2003) for a model with multiple steady states, one with low tax and unemployment rates and one with high tax and unemployment rates, applied to the U.S.-Europe comparison of labor market outcomes.
} 
declined most for the low- and middle-skill groups. ${ }^{35}$ Taken at face value, this preliminary evidence is not favorable to the hypothesis discussed in this section. However, one has to be cautious in interpreting these results because this work does not control for unobserved heterogeneity. ${ }^{36}$ Suppose that - as documented by Card (1996) - unobserved ability is higher among unionized workers with low observable skills. Given that unionized firms offer a compressed wage schedule, such a contract would attract the highest ability workers with low education and the lowest ability workers with high education. Moreover, assume that technological change induces a rise in the market return for innate ability, as discussed earlier. Then, the theory suggests that one should observe exactly the cross-skill de-unionization pattern documented from U.S. and U.K. data.

It should be mentioned that a technology-based theory of deunionization must also explain why union density did not fall (in fact, it expanded somewhat) in the public sector. Since the public sector is, by definition, sheltered from the international competition, it is reasonable to conjecture that the leap in competitive pressure faced by many manufacturing industries over the past 30 years eroded those rents that are, according to some researchers, at the heart of the existence of unions. A quantitative evaluation of the importance of this channel is yet to be performed.

Another avenue that so far has not been pursued is the analysis of deunionization in conjunction with the structural changes in workplace organization that occurred in the past 30 years. In Section 4 , we argued that a distinct feature of the recent change in the production process, especially in manufacturing, is the switch from Tayloristic organizations, where workers repeatedly performed similar tasks around the conveyer belt, towards "flatter" organization built on teams where workers engage in multiple tasks and where the individual division of labor is much fuzzier. Union's wage setting arrangements, based on "equal pay for equal work", can be effective within a Tayloristic plant, but then become very inefficient in plants where production is organized through teams. There is no reason to assume that workers performing the same task will be equally productive, since they perform many other complementary operations simultaneously (see, e.g., Lindbeck and Snower, 1996).

\section{Technology-Policy Complementarity: United States vs. Europe}

A large portion of this chapter has been dedicated to the analysis of a number of different economic models designed to decipher the dynamics of the U.S. wage distribution over the past three decades,

\footnotetext{
${ }^{35}$ Note that wages in the union sector do not fully reflect skills. For this reason, these authors impute skill deciles to unionized workers based on what workers with similar observable characteristics (age, education, gender, race, etc.) would earn in the non-union sector.

${ }^{36}$ Card (2001) makes a rough adjustment for unobserved heterogeneity, based on Card (1996). A thorough analysis would require the use of longitudinal data, but both, Card (2001) and Addison et al. (2004), are restricted to repeated cross-sections.
} 
in light of changes in technology.

In this section we expand our viewpoint to include other dimensions of labor market inequality, which allows us to contrast the U.S. experience with the European experience. In Section 2 we documented that while wage inequality soared in the United States, both the labor share of income and the unemployment rate remained remarkably stable there. In sharp contrast, in most of the large continental European economies, the wage structure did not change much at all, while the labor share fell substantially and unemployment increased steadily. In particular, the increase in European unemployment largely reflects longer durations rather than higher unemployment incidence.

\subsection{The Krugman Hypothesis}

Why have we observed such different outcomes for two regions of the world standing at a similar level of development and, therefore, being subject to very similar aggregate shocks? Are we witnessing a sort of devil's bargain, i.e., a trade-off between inequalities: low unemployment can only be achieved by paying the price of soaring wage inequality? And, if so, what determines the position of each country along this trade-off?

In Table 2 we report, for the set of countries from Table 1, some indexes of the rigidity of various labor market institutions reproduced from Nickell and Layard (1999). The conclusion is unambiguous: compared to the United States, continental Europe has stricter employment protection legislation, more generous and longer unemployment benefits, less decentralized wage bargaining, and more binding minimum wage law.

\section{TABLE 2}

The large majority of papers in the literature have taken the data exhibited in Table 2 as uncontroversial evidence that the reason for the observed differences can be found in the differences in labor market institutions between United States and Continental Europe. Krugman (1994) was probably the first to provide a simple formalized model of this hypothesis. Simply put, the interaction between a severe technological shock and rigid European institutions have induced an adjustment through equilibrium quantities of labor (i.e., the employment distribution), whereas in the flexible U.S. labor market, the adjustment occurred through prices (i.e., the wage distribution).

Several authors have tried to test the Krugman hypothesis econometrically. The typical analysis is based on a cross-country panel of institutions and shocks, i.e., it allows for changing institutions over time, beyond aggregate shocks. A statistical model linking shocks and institutions to the dynamics of unemployment and wage inequality is estimated to evaluate the role of shocks and institutions, first separately and then interacted. The shocks considered are usually of technological 
nature and are measured through changes in measured TFP and changes in the labor share of income, possibly capturing a form of capital-biased technical change. In all cases the shock is assumed to be common across countries.

Blanchard and Wolfers (2000) argue that changing institutions alone have little explanatory power. The performance of the statistical model in explaining cross-country patterns of unemployment rates improves once shocks and institutions are interacted: an equal-size technological shock has differential effects on unemployment when labor market institutions differ. Bertola et al. (2001) provide further evidence for this view. Bentolila and Saint-Paul (1999) also study the evolution of the labor share across OECD countries since 1970. Using panel data techniques, they find that in the presence of institutions that promote wage rigidity, shocks that reduce employment also significantly reduce the labor share of income. One common problem in this empirical literature is that the results are, in general, not robust to the chosen specification. ${ }^{37}$

Another problem of this methodology is that the economic mechanism behind the interaction between technology and policy is not explicit. Consistently with the approach we took in the chapter so far, we will devote more space to quantitative analyses based on "structural" equilibrium models. In the rest of this section, we present the various frameworks the literature has explored to understand the interactions between technological progress and labor market institutions in shaping the various dimensions of inequality. We have grouped these frameworks into six categories, according to the type of technological shock modeled: 1) a rise in microeconomic turbulence, linked to some fundamental change in technology, 2) a slowdown in total factor productivity, 3) an acceleration in the rate of capital-embodied productivity improvements, 4) skill-biased technical change, $5)$ a technological innovation whose adoption is endogenous, and 6) the structural transformation from manufacturing to services.

\subsection{Rise in Microeconomic Turbulence}

In Section 2 we have documented that roughly one-half of the rise in cross-sectional wage differentials in the United States is not associated to a higher return to permanent skills. Rather, it is due to increased wage "instability" over the workers' life time. In other words, transitory idiosyncratic shocks to labor productivity and wages have become more important over time (Gottschalk and Moffitt 1994). These larger temporary wage movements constitute important evidence that there has been a rise in the degree of microeconomic turbulence in the U.S. economy.

More evidence comes from the firm side. Campbell et al. (2001) show that the cross-sectional variability of individual stock returns has trended upward from 1962 to 1997. Chaney et al. (2003)

\footnotetext{
${ }^{37}$ The recent results in Nickell and Nunziata (2002) seem to support an explanation of cross-country unemployment differentials largely based on changing institutions, with a common technological shock playing only a minor role.
} 
and Comin and Mulani (2003) use Compustat firm-level data to demonstrate that the firm-level volatility of real variables, such as investment and sales, has gone up from 1970-1975 to 19901995. Overall, these papers provide snapshots, from very different angles, of an economy where idiosyncratic turbulence and volatility have risen to a high level.

Bertola and Ichino (1995) and Ljungqvist and Sargent $(1998,2003)$ argue that a rise in microeconomic turbulence that interacted with more or less rigid institutions can explain the U.S.-Europe dichotomy. Interestingly, the former authors identify wage rigidity and strict employment protection laws as the culprits, while the latter emphasize the generosity of unemployment benefits. Note, though, that one key premise behind these theories is that the surge in turbulence is common to the United States and Europe. We are not aware of any empirical work documenting trends in microeconomic instability in continental Europe. Currently, this represents a limit for this class of explanations.

\section{Concluding Remarks}

This chapter argues that labor market inequalities are shaped by technological change through a variety of economic mechanisms. Within the technology-labor market nexus, however, which of the specific mechanisms we evaluate are most likely to survive the test of time?

Before answering this question, it is useful to put things in perspective and recall that most of the statements we have made in this chapter are not all meant to represent general insights; rather, they allude to a particular historical episode. Specifically, technology has not always been skillbiased in the past: the transformation from artisanal workplaces to the factory in the 19th century had much the opposite effect (Goldin and Katz, 1998). Moreover, not all the drastic productivity advancements in the past were embodied in equipment: electricity was to a large extent embodied in new structures, as the electrification of production required a whole new blueprint for the plant (Atkeson and Kehoe, 2002). Even in reference to this particular historical episode, there are serious dissenting views on the overall impact of IT on the macroeconomy (e.g., Gordon 2000) and on the role of technology in explaining the observed changes in the U.S. wage structure (e.g., Card and DiNardo, 2002).

In returning to the original question, we identify three rather general categories that we find particularly interesting and plausible.

The first idea is factor-specificity of the recent technological advancements. In particular, the embodiment of productivity improvements in equipment capital goods, and the skill-bias of such productivity improvements. Whether in the Nelson-Phelps version of skills as a vehicle of adoption and innovation, or in the version of skills and capital as complementary in production, the skill-bias 
of the IT revolution is one of the most robust and pervasive in the literature. Skill-biased technical change and capital-skill complementarity are crucial to explain the climb of the skill premium, notwithstanding the continuous growth in the relative supply of skilled labor. A growing and promising avenue of research is on the endogenous determinants of the factor-bias in technological advancements (Acemoglu 2002b, 2003b).

The second idea is vintage human capital. The technological specificity of knowledge appears to be an important idea to explain some of the most puzzling aspects of the data such as the rise in within-group or "residual" inequality, the fall of the real wages at the bottom of the skill distribution, the growth in the returns to experience, and the slowdown of output growth in the aftermath of a technological revolution.

The third idea is the interaction between technology and the organization of labor markets. Radical technological developments, like those we have witnessed in the past three decades, are bound to interact deeply with the various aspects of the structure of labor markets, like the organization of production within the firm, labor unions, and labor market policies. Through this interaction, the literature has successfully interpreted the move from the Tayloristic to the flatter multi-tasking organizational design of firms, the decline of unionization, and the upward trend in unemployment rate in Europe. In particular, the comparison of the U.S. and European experiences seems a fruitful way of studying this channel.

These ideas are the building blocks of the most successful and influential papers in the first generation of models that we have surveyed in this chapter. Where will the literature go next? We argued in various parts of the chapter that one major weakness of this literature is the scarcity of rigorous quantitative evaluations of the theories proposed. Most of the papers reviewed are qualitative in nature. This is not too surprising, given the young vintage of the literature (which developed only starting from the mid 1990s), and given that, in any field, it naturally takes a long time before a handful of theoretical frameworks emerge as successful and begin to be used for a systematic quantitative accounting of the facts (e.g., the search and matching model in the theory of unemployment, and the neoclassical and the endogenous growth model in the theory of cross-country income differences). In this chapter we have highlighted some features that seem important for a successful theory of the link between technological change and labor market outcomes. Quantitative theory should be a priority within this field of research over the years to come. 


\section{References}

[1] Aaronson, S. (2003), "The Rise in Lifetime Earnings Inequality Among Men," mimeo, Federal Reserve Board.

[2] Abowd J.M., F. Kramarz, and D.N. Margolis (1999), "High Wage Workers and High Wage Firms," Econometrica 67, 251-334.

[3] Abraham A. (2003), "Wage Inequality and Education Policy with Skill-biased Technological Change in OG Setting ," mimeo, Duke University.

[4] Acemoglu, D. (1998), "Why Do New Technologies Complement Skills? Directed Technical Change and Wage Inequality," Quarterly Journal of Economics 113, 1055-1090.

[5] Acemoglu, D. (1999), "Changes in Unemployment and Wage Inequality: An Alternative Theory and Some Evidence," American Economic Review 89, 1259-78.

[6] Acemoglu, D. (2002a), "Technical Change, Inequality and the Labor Market," Journal of Economic Literature 40, 7-72.

[7] Acemoglu, D. (2002b), "Directed Technical Change," Review of Economic Studies 69, 781-810.

[8] Acemoglu, D. (2003a), "Cross-Country Inequality Trends," Economic Journal 113, F121-149.

[9] Acemoglu, D. (2003b), "Labor- and Capital-Augmenting Technical Change," Journal of the European Economic Association 1, 1-37.

[10] Acemoglu, D. (2003c), "Patterns of Skill Premia," Review of Economic Studies 70, 199-230.

[11] Acemoglu, D., and J.-S. Pischke (1999), "The Structure of Wages and Investment in General Training," Journal of Political Economy 107, 539-72.

[12] Acemoglu, D., P. Aghion and G.L. Violante (2001), "Deunionization, Technical Change, and Inequality", Carnegie-Rochester Conference Series on Public Policy 55, 29-64.

[13] Addison, J.T., R.W Bailey and W.S. Siebert (2004), "The Impact of Deunionization on Earnings Dispersion Revisited", Departmental Working Paper 14172, Department of Commerce, University of Birmingham.

[14] Aghion, P. (2002), "Schumpeterian Growth Theory and the Dynamics of Income Inequality," Econometrica $70,855-82$.

[15] Aghion, P. and P. Howitt (1994), "Growth and Unemployment," Review of Economic Studies 61, 477-494.

[16] Aghion, P. and P. Howitt (1998), Endogenous Growth Theory, (MIT Press: Cambridge and London).

[17] Aghion, P., P. Howitt and G.L. Violante (2002), "General Purpose Technology and Within-Group Wage Inequality," Journal of Economic Growth 7, 315-345.

[18] Albrecht, J. and S. Vroman (2002), "A Matching Model with Endogenous Skill Requirements," International Economic Review 43, 283-305.

[19] Atkeson, A. and P.J. Kehoe (2002), "The Transition to a New Economy Following the Second Industrial Revolution," NBER Working Papers 8676

[20] Attanasio, O., E. Battistin and H. Ichimura (2003), "What Really Happened to Consumption Inequality in the US?" mimeo, Institute of Fiscal Studies.

[21] Attanasio, O. and S.J. Davis (1996), "Relative Wage Movements and the Distribution of Consumption," Journal of Political Economy 104, 1227-62. 
[22] Autor, D., L. Katz and A. Krueger (1998), "Computing Inequality: Have Computers Changed the Labor Market?" Quarterly Journal of Economics 113, 1169-1213.

[23] Bahk, B.H. and M. Gort (1993), "Decomposing Learning by Doing in New Plants," Journal of Political Economy 101, 561-583.

[24] Baker, G.P. and T.N. Hubbard (2003), "Contractibility and Asset Ownership: On-Board Computers and Governance in U.S. Trucking," American Economic Review 93, 1328-1353.

[25] Bartel A.P. and F.R. Lichtenberg (1987), "The Comparative Advantage of Educated Workers in Implementing New Technology," Review of Economics and Statistics 69, 1-11.

[26] Bartel, A. and N. Sicherman (1998), "Technological Change and the Skill Acquisition of Young Workers," Journal of Labor Economics 16, 718-755.

[27] Basu, S., J. Fernald, N. Oulton and S. Srinivasan (2003), "The Case of the Missing Productivity Growth: Or, Does information technology explain why productivity accelerated in the United States and not in the United Kingdom?," NBER Macroeconomics Annual 18 (MIT Press: Cambridge and London, 9-63.

[28] Beaudry, P. and D.A. Green (2003), "Wages and Employment in the United States and Germany: What Explains the Differences?" American Economic Review 93, 573-602.

[29] Becker, G. (1973), "A Theory of Marriage", Journal of Political Economy 81, 813-846.

[30] Bentolila, S. and G. Saint-Paul (1999), "Explaining Movements in the Labor Share," Contributions to Macroeconomics 3 (1).

[31] Bertola, G. and A. Ichino (1995), "Wage Inequality and Unemployment: United States vs. Europe," in B. Bernanke and J. Rotemberg, eds., NBER Macroeconomics Annual 10 (MIT Press: Cambridge and London), 13-54.

[32] Bertola, G., F.D. Blau and L.M. Kahn (1997), "Swimming Upstream: Trends in the Gender Wage Differential in 1980s," Journal of Labor Economics 15, 1-42.

[33] Bertola, G., F.D. Blau and L.M. Kahn (2001), "Comparative Analysis of Labor Market Outcomes: Lessons for the United States from International Long-Run Evidence," in: A.B. Krueger and R.M. Solow, eds., The roaring nineties: Can full employment be sustained? (Century Foundation Press: New York), 159-218.

[34] Bils, M. and P. Klenow (2004), "Measuring Quality Change and Externalities," in: P. Aghion and S. Durlauf, eds., Handbook of Economic Growth, (North-Holland: Amsterdam).

[35] Blanchard, O. (1997), "The Medium Run," Brookings Papers of Economic Activity (Macroeconomics) $2,89-141$.

[36] Blanchard, O. and J. Wolfers (2000), "The Role of Shocks and Institutions in the Rise of European Unemployment: The Aggregate Evidence," Economic Journal 110, C1-33.

[37] Bleaney, M. (1996), "Central Bank Independence, Bargaining Structure, and Macroeconomic Performance in the OECD Countries," Oxford Economic Papers 48, 20-38.

[38] Blundell, R. and I. Preston (1998), "Consumption Inequality and Income Uncertainty," Quarterly Journal of Economics 113, 603-640.

[39] Bolton, P. and M. Dewatripont (1994), "The Firm as a Communication Network," Quarterly Journal of Economics 109, 809-839.

[40] Booth, A. (1995), The Economics of the Trade Union, (Cambridge University Press: Cambridge, UK).

[41] Borghans, L., and B. ter Weel (2003), "The Diffusion of Computers and the Distribution of Wages," mimeo, Maastricht University 
[42] Bowlus, A.J. and J.-M. Robin (2003), "Twenty Years of Rising Inequality in U.S. Lifetime Labor Income Values," forthcoming Review of Economic Studies.

[43] Braverman, L. (1974), Labor and Monopoly Capital: The Degradation of Work in the Twentieth Century. (Monthly Review Press: New York).

[44] Bresnahan, T.F. and M. Trajtenberg (1995), "General Purpose Technologies: 'Engines of Growth'?" Journal of Econometrics 65, 83-108.

[45] Breshnahan, T.F., E. Brynjolfsson and L.M. Hitt (2002), "Information Technology, Workplace Organization and the Demand for Skilled Labor: Firm-Level Evidence," Quarterly Journal of Economics 117, 339-376.

[46] Brynjolfsson, E. and L.M. Hitt (2000), "Beyond Computation: Information Technology, Organizational Tranformation and Business Performance," Journal of Economic Perspectives 14, 23-48.

[47] Caballero, R.J. and M.L. Hammour (1998), "Jobless Growth: Appropriability, Factor Substitution, and Unemployment," Carnegie-Rochester Conference Series On Public Policy 48, 51-94.

[48] Cain, L. and D. Paterson (1986), "Biased Technical Change, Scale, and Factor Substitution in American Industry, 1850-1919," Journal of Economic History 46, 153-64.

[49] Campbell, J., M. Lettau, B. Malkiel and Y. Xu (2001), "Have Individual Stocks Become More Volatile? An Empirical Exploration of Idiosyncratic Risk," Journal of Finance 56, 1-43.

[50] Card, D. (1996), "The Effects of Unions on the Structure of Wages: A Longitudinal Analysis," Econometrica 64, 957-979.

[51] Card, D. (2001), "The Effects of Unions on Wage Inequality in the U.S. Labor Market," Industrial and Labor Relations Review 54, 296-315.

[52] Card, D. and J. DiNardo (2002), "Skill Biased Technological Change and Rising Wage Inequality: Some Problems and Puzzles," NBER working paper 8769.

[53] Card, D. and T. Lemieux (2001), "Can Falling Supply Explain the Rising Return to College for Younger Men? A Cohort-Based Analysis," Quarterly Journal of Economics 116, 705-46.

[54] Caroli, E. and J. Van Reenen (2001), "Skill-Biased Organizational Change? Evidence From a Panel of British and French Establishments," Quarterly Journal of Economics 116, 1449-1492.

[55] Caselli, F. (1999), "Technological Revolutions," American Economic Review 89, 78-102.

[56] Chaney, T., X. Gabaix and T. Philippon (2003), "The Evolution of Microeconomic and Macroeconomic Volatility," mimeo, NYU Stern.

[57] Chun (2003), "Information Technology and the Demand for Educated Workers: Disentangling the Impacts of Adoption versus Use," Review of Economics and Statistics 85, 1-8.

[58] Coase (1937), "The Nature of the Firm," Economica 4, 386-405

[59] Cohen, D. (1999), "Welfare Differentials Across French and U.S. Labor Markets: A General Equilibrium Interpretation," CEPREMAP working paper 9904.

[60] Cohen-Pirani, D., and R. Castro (2004), "Why Has Skilled Employment Become so Procyclical after 1985?," mimeo Carnegie-Mellon University.

[61] Colecchia, A. and P. Schreyer (2002), "ICT Investment and Economic Growth in the 1990s: Is the United States a Unique Case? A Comparative Study of Nine OECD Countries," Review of Economic Dynamics 5, 408-442.

[62] Comin, D. and Mulani (2003), "Diverging trends in macro and micro volatility: Facts," mimeo NYU. 
[63] Cooley, T.F. and E.C. Prescott (1995), "Economic Growth and Business Cycles," in: T.F. Cooley, ed., Frontiers of Business Cycle Research (Princeton University Press: Princeton), 1-38.

[64] Cozzi G., and G. Impullitti (2004), "Technology Policy and Wage Inequality", mimeo NYU

[65] Cummins, J. and G.L. Violante (2002), "Investment-Specific Technological Change in the U.S. (19472000): Measurement and Macroeconomic Consequences," Review of Economic Dynamics 5, 243-284.

[66] Cutler, D.M. and L.M. Katz (1992), "Rising Inequality? Changes in the Distribution of Income and Consumption in the 1980's," American Economic Review 82, 546-51.

[67] David, P.A. (1990), "The Dynamo and the Computer: An Historical Perspective on the Modern Productivity Paradox," American Economic Review 80, 355-61.

[68] den Haan W.J. (2003), "Temporary Shocks and Unavoidable Transitions to a High-Unemployment Regime," mimeo London Business School.

[69] den Haan, W., C. Haefke and G. Ramey (2001), "Shocks and Institutions in a Job Matching Model", NBER working paper 8463 .

[70] Dickens, R. (2000), "The Evolution of Individual Male Earnings in Great Britain: 1975-1995," Economic Journal 110, 27-49.

[71] Dickens, W.T., and J.S. Leonard (1985), "Accounting for the Decline in Union Membership: 19501980," Industrial and Labor Relations Review 38, 323-34.

[72] DiNardo, J., N.M. Fortin and T. Lemieux (1996), "Labor Market Institutions and the Distribution of Wages, 1973-1992: A Semiparametric Approach," Econometrica 64, 1001-1044.

[73] Dinopolous and Segerstrom (1999), "A Schumpeterian Model of Protection and Relative Wages, " American Economic Review 89, 450-472.

[74] Dooley and Gottschalk (1984), "Earnings Inequality among Males in the United States: Trends and the Effect of Labor Force Growth," Journal of Political Economy 92, 59-89.

[75] Duranton, G. (2004), "The Economics of Production Systems: Segmentation and Skill-Biased Change," European Economic Review 48, 307-36.

[76] Eckstein, Z. and E. Nagypal (2004), "U.S. Earnings and Employment Dynamics 1961-2002: Facts and Interpretations," mimeo Northwestern University.

[77] Farber, H. and A.B. Krueger (1992), "Union Membership in the United States: The Decline Continues," NBER working paper 4216.

[78] Farber, H.S. and B. Western (2000), "Round Up the Usual Suspects: The Decline of Unions in the Private Sector, 1973-1998," Princeton University, Industrial Relations Sections, working paper 437.

[79] Farber, H.S. and B. Western (2002), "Ronald Reagan and the Politics of Declining Union Organization," British Journal of Industrial Relations 40, 385-401.

[80] Flinn, C. (2002), "Labour Market Structure and Inequality: A Comparison of Italy and the U.S." Review of Economic Studies 69, 611-45.

[81] Flug, and Hercowitz (2000), "Equipment Investment and the Relative Demand for Skilled Labor: International Evidence," Review of Economic Dynamics 3, 461-485.

[82] Freeman, R.B (1988), "Contraction and Expansion: The Divergence of Private Sector and Public Sector Unionism in the United States," Journal of Economic Perspectives 2, 63-88.

[83] Freeman, R.B. and E.P. Lazear (1995), "An Economic Analysis of Works Councils," in: J. Rogers and W. Streeck, eds., Works Councils: Consultation, Representation, and Cooperation in Industrial Relations, National Bureau of Economic Research Comparative Labor Markets Series, (University of Chicago Press: Chicago and London), 27-50. 
[84] Freeman, R.B. and J.L. Medoff (1984), "What Unions Do: Evidence, Interpretation, and Directions for Research," Harvard Institute of Economic Research Discussion Paper: 1096.

[85] Friedman, M. (1982), Capitalism and Freedom, (Chicago University Press: Chicago).

[86] Galor, O., and O. Moav (2000), "Ability Biased Technological Transition, Wage Inequality Within and Across Groups, and Economic Growth," Quarterly Journal of Economics 115, 469-97.

[87] Galor, O., and D. Tsiddon (1997), "Technological Progress, Mobility, and Economic Growth," American Economic Review 87, 362-382.

[88] Garicano, L. and E. Rossi-Hansberg (2003), "Organization and Inequality in a Knowledge Economy," mimeo Stanford.

[89] Gittleman, Maury, and Mary Joyce (1996); "Earnings Mobility and Long-Run Inequality: An Analysis Using Matched CPS Data," Industrial Relations 35, 180-197.

[90] Goldin, C. and L.M. Katz (1998), "The Origins of Technology-Skill Complementarity," Quarterly Journal of Economics 113, 693-732.

[91] Goldin, C. and L.M. Katz (1999), "The Returns to Skill in the United States Across the Twentieth Century," NBER working paper 7126.

[92] Goldin, C. and R. Margo (1992), "The Great Compression: The Wage Structure in the United States at Mid-Century," Quarterly Journal of Economics 107, 1-34.

[93] Gordon, R.J. (1990), The Measurement of Durable Good Prices, (University of Chicago Press: Chicago).

[94] Gordon, R.J. (2000), "Does the 'New Economy' Measure Up to the Great Inventions of the Past?" Journal of Economic Perspectives 14, 49-74.

[95] Gosling, A. and S. Machin (1995), "Trade Unions and the Dispersion of Earnings in British Establishments, 1980-90," Oxford Bulletin of Economics and Statistics 57, 167-84.

[96] Gottschalk, P. and R. Moffitt (1994), "The Growth of Earnings Instability in the U.S. Labor Market," Brookings Papers of Economic Activity 2, 217-272.

[97] Gottschalk, P. and T.M. Smeeding (1997), "Cross-National Comparisons of Earnings and Income Inequality," Journal of Economic Literature 35, 633-687.

[98] Gould, E.D., O. Moav and B.A. Weinberg (2001), "Precautionary Demand for Education, Inequality and Technological Progress," Journal of Economic Growth 6, 285-315.

[99] Gould, E.D. and M.. Paserman (2003), "Waiting for Mr. Right: Rising Inequality and Declining Marriage Rates," Journal of Urban Economics 53, 257-281.

[100] Greenwood, J. and B. Jovanovic (1999), "The IT Revolution and the Stock Market," American Economic Review 89, 116-122.

[101] Greenwood, J. and A. Seshadri (2004), "Technological Progress and Economic Transformation," in: P. Aghion and S. Durlauf, eds., Handbook of Economic Growth, (North-Holland: Amsterdam).

[102] Greenwood J. and M. Yorukoglu (1997), "1974," Carnegie-Rochester Conference Series on Public Policy 46, 49-96.

[103] Greenwood, J., Z. Hercowitz and P. Krusell (1997), "Long-Run Implications of Investment-Specific Technological Change," American Economic Review 87, 342-362.

[104] Greenwood, J., A. Seshadri and M. Yorukoglu (2004), "Engines of Liberation," Review of Economic Studies, forthcoming.

[105] Griliches, Z. (1969), "Capital-Skill Complementarity," Review of Economics and Statistics 5, 465-68. 
[106] Haider, S. (2001), "Earnings Instability and Earnings Inequality of Males in the United States: 19671991," Journal of Labor Economics 19, 799-836.

[107] Hall, R.E. (1973), "The Specification of Technology with Several Kinds of Output," Journal of Political Economy 81, 878-892.

[108] Hall, R.E. (2001), "The Stock Market and Capital Accumulation," American Economic Review 95, 1185-1202.

[109] Hamermesh, D.S. (1993), Labor Demand, (Princeton University Press: Princeton, NJ)..

[110] Hansen, H. (1998), "Transition from Unemployment Benefits to Social Assistance in Seven European OECD Countries," Empirical Economics 23, 5-30.

[111] Hayek, F.A. (1945), "The Use of Knowledge in Society," American Economic Review 35, 519-530.

[112] Heathcote, J., K. Storesletten and G.L. Violante (2003), "The Macroeconomic Implications of Rising Wage Inequality in the U.S.," mimeo NYU.

[113] Heathcote, J., K. Storesletten and G.L. Violante (2004), "Insurance and Opportunites: The Welfare Analysis of Wage Dispersion," mimeo NYU.

[114] Heckman, J.J. (2000), "Policies to Foster Human Capital," Research in Economics 54, 3-56.

[115] Heckman, J.J., L. Lochner and C. Taber (1998), "Explaining Rising Wage Inequality: Explorations with a Dynamic General Equilibrium Model of Labor Earnings with Heterogeneous Agents," Review of Economic Dynamics 1, 1-58.

[116] Helpman, E. and A. Rangel (1999), "Adjusting to a New Technology: Experience and Training," Journal of Economic Growth 4, 359-383.

[117] Ho, M.S. and D.W. Jorgenson (1999), "The Quality of the U.S. Workforce," mimeo Harvard University.

[118] Hobjin, B. (2000), "Identifying Sources of Growth," mimeo, Federal Reserve Bank of New York.

[119] Holmes, T. and M.F. Mitchell (2004), "A Theory of Factor Allocation and Plant Size," NBER Working Papers 10079.

[120] Hornstein, A. (1999), "Growth Accounting with Technological Revolutions," Federal Reserve Bank of Richmond Economic Quarterly 85 (3), 1-24.

[121] Hornstein, A. (2004), "(Un)Balanced Growth," Federal Reserve Bank of Richmond Economic Quarterly 90 Fall, 25-45.

[122] Hornstein, A. and P. Krusell (1996), "Can Technology Improvements Cause Productivity Slowdowns?", NBER Macroeconomics Annual 11 (MIT Press: Cambridge MA), 209-259.

[123] Hornstein, A. and P. Krusell (2000), "The IT Revolution: Is it Evident in the Productivity Numbers?" Federal Reserve Bank of Richmond Economic Quarterly 86 Fall, 49-78.

[124] Hornstein, A. and P. Krusell (2003), "Implications of the Capital-Embodiment Revolution for Directed R\&D and Wage Inequality," Federal Reserve Bank of Richmond Economic Quarterly 89 Fall, 25-50.

[125] Hornstein, A., P. Krusell and G.L. Violante (2003a), "Vintage Capital in Frictional Labor Markets", mimeo NYU.

[126] Hornstein, A., P. Krusell and G.L. Violante (2003b), "A Quantitative Study of the Replacement Problem in Frictional Economies," mimeo NYU.

[127] Hoxby C.M. and B.T. Long (1998), "Explaining Rising Income and Wage Inequality Among the College-Educated," mimeo harvard University.

[128] Huggett, M. (1996), "Wealth Distribution in Life-Cycle Economies," Journal of Monetary Economics $38,469-94$. 
[129] Huggett, M. and S. Ospina (2001), "Does Productivity Growth Fall After the Adoption of New Technology?" Journal of Monetary Economics 48, 173-95.

[130] Hulten, C.R. (1992), "Growth Accounting When Technical Change is Embodied in Capital," American Economic Review 82, 964-80.

[131] Hyslop, D. (2001), "Rising U.S. Earnings Inequality and Family Labor Supply: The Covariance Structure of Intrafamily Earnings," American Economic Review 91, 755-77.

[132] Ingram B. and G. Neumann (1999), "An Analysis of the Evolution of the Skill Premium, " mimeo University of Iowa.

[133] Irwin, D.A. and P.J. Klenow (1994), "Learning-by-Doing Spillovers in the Semiconductor Industry," Journal of Political Economy 102, 1200-1227.

[134] Iversen, T. (1998), "Wage Bargaining, Central Bank Independence and the Real Effects of Money", International Organization.

[135] Johnson, D. and S. Shipp (1997), "Trends in Inequality Using Consumption-Expenditures in the U.S. from 1960 to 1993," Review of Income and Wealth 43, 133-52.

[136] Jones C. (2004), "Growth and Ideas" in: P. Aghion and S. Durlauf, eds., Handbook of Economic Growth, (North-Holland: Amsterdam).

[137] Jorgenson, D.W. (2001), "Information Technology and the U.S. Economy," American Economic Review 91, 1-32.

[138] Jorgenson, D.W. (2004), "Accounting for Growth in the Information Age," in: P. Aghion and S. Durlauf, eds., Handbook of Economic Growth (North-Holland: Amsterdam).

[139] Jorgenson, D.W. and K.J. Stiroh (2000), "U.S. Economic Growth at the Industry Level," American Economic Review 90, 161-67.

[140] Jorgenson, D.W., F. Gollop and B. Fraumeni (1987), Productivity and U.S. Economic Growth (Harvard University Press: Cambridge MA).

[141] Jovanovic, B. (1998), "Vintage Capital and Inequality," Review of Economic Dynamics 1, 497 - 530.

[142] Jovanovic, B. and Y. Nyarko (1995), "A Bayesian Learning Model Fitted to a Variety of Empirical Learning Curves," Brookings Papers on Economic Activity (Microeconomics), 247-99.

[143] Jovanovic, B. and P. Rousseau (2004a), "General Purpose Technologies," in: P. Aghion and S. Durlauf, eds., Handbook of Economic Growth, (North-Holland: Amsterdam).

[144] Jovanovic, B. and P. Rousseau (2004b), "Specific Capital and the Division of Rents," mimeo NYU.

[145] Juhn, C. (1992), "Decline of Male Labor Market Participation: The Role of Declining Market Opportunities", Quarterly Journal of Economics 107, 79-121.

[146] Juhn, C., K. Murphy and B. Pierce (1993), "Wage Inequality and the Rise in Returns to Skill," Journal of Political Economy 101, 410-442.

[147] Kambourov, G. and I. Manovskii (2004), "Occupational Mobility and Wage Inequality", mimeo University of Pennsylvania.

[148] Katz, L. and D. Autor (1999), "Changes in the Wage Structure and Earnings Inequality," in: O. Ashenfelter and D. Card, eds., Handbook of Labor Economics, vol. 3 (North-Holland: Amsterdam), $1463-1555$.

[149] Katz, L. and K. Murphy (1992), "Changes in Relative Wages, 1963-1987: Supply and Demand Factors," Quarterly Journal of Economics 107, 35-78.

[150] Kelly, M. (2000), "Inequality and Crime," The Review of Economics and Statistics 82, 530-539. 
[151] Kiley, M.T. (1999), "The Supply of Skilled Labour and Skill-Biased Technological Progress," The Economic Journal 109, 708-24.

[152] King, I. and L. Welling (1995), "Search, unemployment, and growth," Journal of Monetary Economics $3,499-507$

[153] Kocherlakota, N. (1996), "Implications of Efficient Risk Sharing without Commitment," Review of Economic Studies 63, 595-609.

[154] Kremer, M. and E.S. Maskin (1996), "Wage Inequality and Segregation by Skill," NBER Working Papers 5718.

[155] Krueger A.B. and L.H. Summers (1988), "Efficiency Wages and the Inter-Industry Wage Structure," Econometrica 56, 259-93.

[156] Krueger, D., and Kumar (2004); "Skill-specific rather than General Education: A Reason for USEurope Growth Differences?," Journal of Economic Growth 9, 167-207.

[157] Krueger, D. and F. Perri (2002), "Does Income Inequality Lead to Consumption Inequality? Evidence and Theory", mimeo Stanford.

[158] Krueger, D. and F. Perri (2003), "On the Welfare Consequences of the Increase in Inequality in the United States," in: M. Gertler and K. Rogoff, eds., NBER Macroeconomics Annual 18, (MIT Press: Cambridge, MA).

[159] Krugman, P. (1994), "Past and Prospective Causes of High Unemployment," Economic Review (Federal Reserve Bank of Kansas City) 79 (4), 23-43.

[160] Krusell, P., L. Ohanian, J.-V. Rios-Rull and G.L. Violante (2000), "Capital Skill Complementarity and Inequality: A Macroeconomic Analysis," Econometrica 68, 1029-1053.

[161] LaLonde, R.J., J.J. Heckman and J. Smith (1999), "The Economics and Econometrics of Active Labor Market Programs," in: O. Ashenfelter and D. Card, eds., Handbook of Labor Economics, Vol 3A (North-Holland: Amsterdam), 1865-2097.

[162] Lee, D. and K. Wolpin (2004), "Intersectoral Labor Mobility and the Growth of the Service Sector", mimeo NYU.

[163] Levy, P.A. (1985), "The Unidimensional Perspective of Reagan's Labor Board", Rutgers Law Journal $16,269-390$.

[164] Levy, F. and R. J. Murnane (1992), "U.S. Earnings Levels and Earnings Inequality: A Review of Recent Trends and Proposed Explanations", Journal of Economic Literature 30, 1333-1381.

[165] Lillard, L.A. and H.W. Tan (1986), "Training: Who Gets It and What Are Its Effects on Employment and Earnings?" (Santa Monica: RAND Corporation Report R-3331-DOL/RC).

[166] Lindbeck, A. and D.J. Snower (1996), "Reorganization of Firms and Labor Market Inequality," American Economic Review, P\&P 86, 315-321.

[167] Lindquist, M.J. (2002), "Capital-Skill Complementarity and Inequality in Sweden," mimeo Uiversity of Stockholm.

[168] Lindquist, M.J. (2004), "Capital-Skill Complementarity and Inequality Over the Business Cycle," Review of Economic Dynamics 7, 519-540.

[169] Lipsey, R.G., C. Bekar and K. Carlaw (1998), "The Consequences of Changes in GPTs," in: E. Helpman, ed., General Purpose Technologies and Economic Growth (MIT Press: Cambridge MA), 193-218.

[170] Ljungqvist, L. and T.J. Sargent (1998), "The European Unemployment Dilemma," Journal of Political Economy 106, 514-50. 
[171] Ljungqvist, L. and T.J. Sargent (2003), "European Unemployment and Turbulence Revisited in a Matching Model," mimeo NYU.

[172] Lloyd-Ellis, H. (1999), "Endogenous Technological Change and Wage Inequality," American Economic Review 89, 47-77.

[173] Lucas, R.E. Jr. (1993), "Making a Miracle," Econometrica 61, 251-72.

[174] Lucas, R.E. Jr. (2003), "Macroeconomic Priorities," American Economic Review 93, 1-14.

[175] Lucas, R.E. Jr. and E.C. Prescott (1974), "Equilibrium Search and Unemployment," Journal of Economic Theory 7, 188-209.

[176] Machin, S. (1996), "Wage Inequality in the UK," Oxford Review of Economic Policy 12, 47-64.

[177] Machin, S. (2000), "Union Decline in Britain," British Journal of Industrial Relations 38, 631-45.

[178] Machin, S. (2003), "New Workplaces, New Workers: Trade Union Decline and the New Economy", forthcoming in H. Gospel and S. Wood, eds., The Future of Unions ,Volume 1 (Routledge: London).

[179] Manuelli, R. (2000), "Technological Change, the Labor Market, and the Stock Market", NBER Working Papers 8022.

[180] Marimon, R. and F. Zilibotti (1999), "Unemployment vs. Mismatch of Talents: Reconsidering Unemployment Benefits," Economic Journal 109, 266-91.

[181] McCall, J.J. (1970), “Economics of Information and Job Search," Quarterly Journal of Economics 84, 113-26.

[182] McConnell, S. (1996), "The Role of Computers in Reshaping the Workforce," Monthly Labour Review 119 (August), 3-5.

[183] McGrattan, E., and E.C. Prescott (2003), "Taxes, Regulations, and the Value of U.S. Corporations: A General Equilibrium Analysis," Staff Report 309, Federal Reserve Bank of Minneapolis.

[184] Meghir, C. and L. Pistaferri (2004), "Income Variance Dynamics and Heterogeneity", Econometrica $72,1-32$.

[185] Milgrom, P. and J. Roberts (1990), "The Economics of Modern Manufacturing: Technology, Strategy,and Organization," American Economic Review 80, 511-528.

[186] Mincer, J. and Y. Higuchi (1991), "Wage Structures and Labor Turnover in the United States and Japan," Journal of the Japanese and International Economies 2, 97-133.

[187] Mitchell, M.F. (2001), "Specialization and the Skill Premium in the 20th Century," Staff Report 290, Federal Reserve Bank of Minneapolis

[188] Möbius, M. (2000), "The Evolution of Work", mimeo Harvard.

[189] Moen, E.R. (1997), "Competitive Search Equilibrium," Journal of Political Economy 105, 385- 411.

[190] Mortensen, D.T. and C.A. Pissarides (1998), "Technological Progress, Job Creation, and Job Destruction," Review of Economic Dynamics 1, 733-53.

[191] Mortensen, D.T. and C.A. Pissarides (1999), "Unemployment Responses to 'Skill-Biased' Technology Shocks: The Role of Labour Market Policy," Economic Journal 109, 242-65.

[192] Murphy, K. and R. Topel (1997), "Unemployment and Nonemployment," American Economic Review $P \mathscr{P} P$ 87, 295-300.

[193] Murphy, K. and F. Welch (1992), "The Structure of Wages," Quarterly Journal of Economics 107, 285-326. 
[194] Nelson, R.R. and E.S. Phelps (1966), "Investment in Humans, Technological Diffusion, and Economic Growth," American Economic Review 56, 69-75.

[195] Neumark, D. (2000), "Changes in Job Stability and Job Security: A Collective Effort to Untangle, Reconcile and Interpret the Evidence," in: D. Neumark, ed., On the Job: Is Long-Term Employment a Thing of the Past? (Russell Sage Foundation: New York), 1-27.

[196] Nickell, S. and B. Bell (1996), "Changes in the Distribution of Wages and Unemployment in OECD Countries," American Economic Review P\&P 86, 302-08.

[197] Nickell, S. and R. Layard (1999), "Labor Market Institutions and Economic Performance," in: O. Ashenfelter and D. Card, eds., Handbook of Labor Economics, vol. 3C (North Holland: Amsterdam), 3029-84.

[198] Nickell, S. and L. Nunziata (2002), "Unemployment in the OECD since the 1960s: What Do We Know?" mimeo, Bank of England.

[199] OECD Employment Outlook (1996), OECD: Paris.

[200] Oliner, S.D. and D.E. Sichel (2000), "The Resurgence of Growth in the Late 1990s: Is Information Technology the Story?" Journal of Economic Perspectives 14, 3-22.

[201] Ortigueira, S. (2002), "The Rise and Fall of Centralized Wage Bargaining," mimeo Cornell.

[202] Piketty, T. and E. Saez (2003), "Income Inequality in the United States, 1913-1998," Quarterly Journal of Economics 118, 1-39.

[203] Piore, M.J. and C. F. Sabel.(1984), The Second Industrial Divide, (Basic Books: New York).

[204] Pissarides, C.A. (2000), Equilibrium Unemployment Theory, (MIT Press: Cambridge MA).

[205] Rajan, R. and J. Wulf (2003), "The Flattening Firm: Evidence from Panel Data on the Changing Nature of Corporate Hierarchies," mimeo Chicago GSB.

[206] Robbins D. (1996), "Evidence on Trade and Wages in Developing World," OECD Technical Papers 119.

[207] Rogerson, R. (2004), "Two Views on the Deterioration of European Labor Market Outcomes," Journal of the European Economic Association 2, 447-455.

[208] Rosen, S. (1981), "The Economics of Superstars," American Economic Review 71, 845-58.

[209] Ruiz-Arranz, M. (2002). "Wage Inequality in the U.S.: Capital-Skill Complementarity vs. Skill-Biased Technological Change," mimeo, Harvard University.

[210] Saint-Paul, G. (2001), "On the Distribution of Income and Worker Assignment under Intrafirm Spillovers, with an Application to Ideas and Networks," Journal of Political Economy 109, 1-37.

[211] Sakellaris, P. and D.J. Wilson (2004), "Quantifying Embodied Technical Change", Review of Economic Dynamics 7, 1-26.

[212] Sattinger, M. (1995), "Search and the Efficient Assignment of Workers to Jobs," International Economic Review 36, 283-302.

[213] Shi, S. (2002), "A Directed Search Model of Inequality with Heterogeneous Skills and Skill-Based Technology," Review of Economic Studies 69, 467-91.

[214] Solow, R. (1957), "Technical Change and the Aggregate Production Function," Review of Economics and Statistics 39, 312-320.

[215] Solow, R. (1960), "Investment and Technological Progress," in: K. Arrow, S. Karlin, and P. Suppes, eds., Mathematical Methods in the Social Sciences (Stanford University Press: Stanford CA), 89-104. 
[216] Thesmar, D. and M. Thoenig (2000), "Creative Destruction and Firm Organization Choice", Quarterly Journal of Economics 115, 1201-37.

[217] Violante, G.L. (2002), "Technological Acceleration, Skill Transferability and the Rise in Residual Inequality," Quarterly Journal of Economics 117, 297-338.

[218] Weinberg, B.A. (2003a), "Computer Use and the Demand for Women Workers," Industrial and Labor Relations Review 53, 290-308.

[219] Weinberg, B.A. (2003b), "Experience and Technology Adoption," Working Paper.

[220] Wong, L.Y. (2003), "Can the Mortensen-Pissarides Model with Productivity Changes Explain U.S. Wage Inequality?" Journal of Labor Economics 21, 70-105. 
Cross-country labor market data (1965-1995)

\begin{tabular}{|c|c|c|c|c|c|c|c|c|c|}
\hline & & 1965 & 1970 & 1975 & 1980 & 1985 & 1990 & 1995 & Change \\
\hline Austria & $\begin{array}{l}\text { Unemp. Rate } \\
\text { Labor share } \\
\text { Inequality }\end{array}$ & $\begin{array}{l}0.018 \\
0.698\end{array}$ & $\begin{array}{l}0.011 \\
0.679\end{array}$ & $\begin{array}{l}0.017 \\
0.717\end{array}$ & $\begin{array}{l}0.029 \\
0.694 \\
0.820\end{array}$ & $\begin{array}{l}0.045 \\
0.665 \\
0.790\end{array}$ & $\begin{array}{l}0.054 \\
0.646 \\
0.870\end{array}$ & $\begin{array}{l}0.061 \\
0.645 \\
0.880\end{array}$ & $\begin{array}{c}0.043 \\
-0.053 \\
0.060\end{array}$ \\
\hline Belgium & $\begin{array}{l}\text { Unemp. Rate } \\
\text { Labor share } \\
\text { Inequality }\end{array}$ & 0.023 & $\begin{array}{l}0.022 \\
0.667\end{array}$ & $\begin{array}{l}0.064 \\
0.729\end{array}$ & $\begin{array}{l}0.114 \\
0.730\end{array}$ & $\begin{array}{l}0.111 \\
0.682 \\
0.660\end{array}$ & $\begin{array}{l}0.110 \\
0.685 \\
0.650\end{array}$ & $\begin{array}{l}0.142 \\
0.676 \\
0.640\end{array}$ & $\begin{array}{l}0.120 \\
0.009 \\
-0.020\end{array}$ \\
\hline Denmark & $\begin{array}{l}\text { Unemp. Rate } \\
\text { Labor share } \\
\text { Inequality }\end{array}$ & $\begin{array}{l}0.014 \\
0.736\end{array}$ & $\begin{array}{l}0.016 \\
0.723\end{array}$ & $\begin{array}{l}0.061 \\
0.732\end{array}$ & $\begin{array}{l}0.093 \\
0.706 \\
0.760\end{array}$ & $\begin{array}{l}0.085 \\
0.677 \\
0.770\end{array}$ & $\begin{array}{l}0.112 \\
0.635 \\
0.770\end{array}$ & $\begin{array}{l}0.103 \\
0.605\end{array}$ & $\begin{array}{c}0.089 \\
-0.131 \\
0.010\end{array}$ \\
\hline Finland & $\begin{array}{l}\text { Unemp. Rate } \\
\text { Labor share } \\
\text { Inequality }\end{array}$ & $\begin{array}{l}0.025 \\
0.738\end{array}$ & $\begin{array}{l}0.021 \\
0.711\end{array}$ & $\begin{array}{l}0.050 \\
0.762\end{array}$ & $\begin{array}{l}0.051 \\
0.730 \\
0.890\end{array}$ & $\begin{array}{l}0.047 \\
0.723 \\
0.920\end{array}$ & $\begin{array}{l}0.121 \\
0.733 \\
0.940\end{array}$ & $\begin{array}{l}0.167 \\
0.680 \\
0.930\end{array}$ & \\
\hline France & $\begin{array}{l}\text { Unemp. Rate } \\
\text { Labor share } \\
\text { Inequality }\end{array}$ & $\begin{array}{l}0.020 \\
0.688\end{array}$ & $\begin{array}{l}0.027 \\
0.674\end{array}$ & $\begin{array}{l}0.049 \\
0.707\end{array}$ & $\begin{array}{l}0.079 \\
0.710 \\
1.210\end{array}$ & $\begin{array}{l}0.101 \\
0.645 \\
1.210\end{array}$ & $\begin{array}{l}0.105 \\
0.618 \\
1.240\end{array}$ & $\begin{array}{l}0.115 \\
0.603 \\
1.230\end{array}$ & $\begin{array}{c}0.095 \\
-0.085 \\
0.020\end{array}$ \\
\hline Germany & $\begin{array}{l}\text { Unemp. Rate } \\
\text { Labor share } \\
\text { Inequality }\end{array}$ & $\begin{array}{l}0.010 \\
0.685\end{array}$ & $\begin{array}{l}0.011 \\
0.703\end{array}$ & $\begin{array}{l}0.037 \\
0.703\end{array}$ & $\begin{array}{l}0.060 \\
0.704 \\
0.870\end{array}$ & $\begin{array}{l}0.075 \\
0.667 \\
0.830\end{array}$ & $\begin{array}{l}0.078 \\
0.658 \\
0.830\end{array}$ & $\begin{array}{l}0.099 \\
0.637 \\
0.810\end{array}$ & \\
\hline Ireland & $\begin{array}{l}\text { Unemp. Rate } \\
\text { Labor share } \\
\text { Inequality }\end{array}$ & $\begin{array}{l}0.047 \\
0.828\end{array}$ & $\begin{array}{l}0.055 \\
0.842\end{array}$ & $\begin{array}{l}0.078 \\
0.835\end{array}$ & $\begin{array}{l}0.112 \\
0.833\end{array}$ & $\begin{array}{l}0.164 \\
0.763\end{array}$ & $\begin{array}{l}0.146 \\
0.715\end{array}$ & $\begin{array}{l}0.120 \\
0.645\end{array}$ & \\
\hline Italy & $\begin{array}{l}\text { Unemp. Rate } \\
\text { Labor share } \\
\text { Inequality }\end{array}$ & $\begin{array}{l}0.041 \\
0.669\end{array}$ & $\begin{array}{l}0.043 \\
0.687\end{array}$ & $\begin{array}{l}0.051 \\
0.711\end{array}$ & $\begin{array}{l}0.070 \\
0.690 \\
0.850\end{array}$ & $\begin{array}{l}0.099 \\
0.656 \\
0.830\end{array}$ & $\begin{array}{l}0.096 \\
0.653 \\
0.770\end{array}$ & $\begin{array}{l}0.120 \\
0.606 \\
0.970\end{array}$ & $\begin{array}{c}0.079 \\
-0.063 \\
0.120\end{array}$ \\
\hline Vetherlands & $\begin{array}{l}\text { Unemp. Rate } \\
\text { Labor share } \\
\text { Inequality }\end{array}$ & $\begin{array}{l}0.010 \\
0.656\end{array}$ & $\begin{array}{l}0.018 \\
0.687\end{array}$ & $\begin{array}{l}0.038 \\
0.705\end{array}$ & $\begin{array}{l}0.080 \\
0.661\end{array}$ & $\begin{array}{l}0.081 \\
0.623 \\
0.920\end{array}$ & $\begin{array}{l}0.062 \\
0.619 \\
0.960\end{array}$ & $\begin{array}{l}0.071 \\
0.624 \\
0.950\end{array}$ & $\begin{array}{c}0.061 \\
-0.032 \\
0.030\end{array}$ \\
\hline Norway & $\begin{array}{l}\text { Unemp. Rate } \\
\text { Labor share } \\
\text { Inequality }\end{array}$ & $\begin{array}{l}0.016 \\
0.750\end{array}$ & $\begin{array}{l}0.015 \\
0.771\end{array}$ & $\begin{array}{l}0.018 \\
0.782\end{array}$ & $\begin{array}{l}0.026 \\
0.757 \\
0.720\end{array}$ & $\begin{array}{l}0.030 \\
0.739 \\
0.720\end{array}$ & $\begin{array}{l}0.056 \\
0.713 \\
0.680\end{array}$ & 0.049 & $\begin{array}{c}0.034 \\
-0.037 \\
-0.040\end{array}$ \\
\hline Portugal & $\begin{array}{l}\text { Unemp. Rate } \\
\text { Labor share } \\
\text { Inequality }\end{array}$ & $\begin{array}{l}0.040 \\
0.562\end{array}$ & $\begin{array}{l}0.024 \\
0.615\end{array}$ & $\begin{array}{l}0.065 \\
0.873\end{array}$ & $\begin{array}{l}0.079 \\
0.751\end{array}$ & $\begin{array}{l}0.070 \\
0.673\end{array}$ & $\begin{array}{l}0.051 \\
0.679\end{array}$ & $\begin{array}{l}0.073 \\
0.680\end{array}$ & \\
\hline Spain & $\begin{array}{l}\text { Unemp. Rate } \\
\text { Labor share } \\
\text { Inequality }\end{array}$ & $\begin{array}{l}0.028 \\
0.763\end{array}$ & $\begin{array}{l}0.030 \\
0.780\end{array}$ & $\begin{array}{l}0.059 \\
0.788\end{array}$ & $\begin{array}{l}0.161 \\
0.756\end{array}$ & $\begin{array}{l}0.200 \\
0.679\end{array}$ & $\begin{array}{l}0.196 \\
0.669\end{array}$ & $\begin{array}{l}0.230 \\
0.616\end{array}$ & $\begin{array}{r}0.202 \\
-0.147\end{array}$ \\
\hline Sweden & $\begin{array}{l}\text { Unemp. Rate } \\
\text { Labor share } \\
\text { Inequality }\end{array}$ & $\begin{array}{l}0.018 \\
0.724\end{array}$ & $\begin{array}{l}0.022 \\
0.716\end{array}$ & $\begin{array}{l}0.019 \\
0.745\end{array}$ & $\begin{array}{l}0.028 \\
0.711 \\
0.750\end{array}$ & $\begin{array}{l}0.021 \\
0.691 \\
0.760\end{array}$ & $\begin{array}{l}0.052 \\
0.693 \\
0.730\end{array}$ & $\begin{array}{l}0.079 \\
0.630 \\
0.790\end{array}$ & $\begin{array}{c}0.061 \\
-0.095 \\
0.040\end{array}$ \\
\hline UK & $\begin{array}{l}\text { Unemp. Rate } \\
\text { Labor share } \\
\text { Inequality }\end{array}$ & $\begin{array}{l}0.019 \\
0.693\end{array}$ & $\begin{array}{l}0.025 \\
0.699\end{array}$ & $\begin{array}{l}0.044 \\
0.698\end{array}$ & $\begin{array}{l}0.089 \\
0.694 \\
0.920\end{array}$ & $\begin{array}{l}0.091 \\
0.690 \\
1.050\end{array}$ & $\begin{array}{l}0.086 \\
0.712 \\
1.150\end{array}$ & $\begin{array}{l}0.079 \\
0.692 \\
1.200\end{array}$ & $\begin{array}{c}0.060 \\
-0.002 \\
0.280\end{array}$ \\
\hline Canada & $\begin{array}{l}\text { Unemp. Rate } \\
\text { Labor share } \\
\text { Inequality }\end{array}$ & $\begin{array}{l}0.040 \\
0.716\end{array}$ & $\begin{array}{l}0.058 \\
0.660\end{array}$ & $\begin{array}{l}0.076 \\
0.652\end{array}$ & $\begin{array}{l}0.099 \\
0.634 \\
1.240\end{array}$ & $\begin{array}{l}0.089 \\
0.630 \\
1.390\end{array}$ & $\begin{array}{l}0.103 \\
0.666 \\
1.380\end{array}$ & $\begin{array}{l}0.096 \\
0.659 \\
1.330\end{array}$ & $\begin{array}{c}0.056 \\
-0.057 \\
0.090\end{array}$ \\
\hline USA & $\begin{array}{l}\text { Unemp. Rate } \\
\text { Labor share } \\
\text { Inequality }\end{array}$ & $\begin{array}{l}0.038 \\
0.685\end{array}$ & $\begin{array}{l}0.054 \\
0.695\end{array}$ & $\begin{array}{l}0.070 \\
0.675\end{array}$ & $\begin{array}{l}0.083 \\
0.678 \\
1.180\end{array}$ & $\begin{array}{l}0.062 \\
0.665 \\
1.350\end{array}$ & $\begin{array}{l}0.066 \\
0.666 \\
1.380\end{array}$ & $\begin{array}{l}0.055 \\
0.670 \\
1.470\end{array}$ & $\begin{array}{c}0.017 \\
-0.015 \\
0.290\end{array}$ \\
\hline $\begin{array}{l}\text { Europe } \\
\text { Average }\end{array}$ & $\begin{array}{l}\text { Unemp. Rate } \\
\text { Labor share } \\
\text { Inequality }\end{array}$ & $\begin{array}{l}0.024 \\
0.708\end{array}$ & $\begin{array}{l}0.024 \\
0.712\end{array}$ & $\begin{array}{l}0.047 \\
0.753\end{array}$ & $\begin{array}{l}0.076 \\
0.726 \\
0.859 \\
\end{array}$ & $\begin{array}{l}0.087 \\
0.683 \\
0.841\end{array}$ & $\begin{array}{l}0.095 \\
0.670 \\
0.844\end{array}$ & $\begin{array}{l}0.110 \\
0.637 \\
0.900\end{array}$ & $\begin{array}{c}0.086 \\
-0.062 \\
0.040\end{array}$ \\
\hline
\end{tabular}

Note: Data on unemployment rates are from Blanchard and Wolfers (2000). Data on labor shares are from Blanchard and Wolfers (2000) except the 1995 entry for Austria, Denmark, shares are from Blanchard and Wolfers (2000) except the 1995 entry for Austria, Denmark,
Ireland and Portugal which was computed directly from OECD data. Inequality is measured Ireland and Portugal which was computed directly from OECD data. Inequality is measured Employment Outlook (1996, Table 3.1). Austria: the measure is the 80-10 differential and data Employment Outlook (1996, Table 3.1). Austria: the measure is the 80-10 differential and data in the 1985 column are for 1987. Belgium: the measure is the $80-10$ differential and data in the 1995 column are for 1993. Denmark. 1985 and 1990 columns are for 1983 and 1991 respectively. Finland: data in the 1985 column are for 1986. Germany: data in the 1985 and 1995 columns are for 1983 and 1993 respectively. Italy: data in the 1985, 1990 and 1995 columns are for 1984, 1991 and 1993 respectively. Netherlands: the measure of inequality is for males and females. Norway: data in the 1985 and 1990 columns are for 1983 and 1991 respectively. Moreover, the measure of inequality is for males and females. Portugal: data in the 1990 and 1995 columns are for 1989 and 1993 respectively. Canada: data in the 1980 and 1985 columns are for 1981 and 1986 respectively. For all countries, except US and UK, data in the 1995 column are for 1994. Europe average: unweighted mean of European countries, except UK.

Table 1: Data on the evolution of the labor share, the unemployment rate, and wage inequality across OECD countries from 1965-1995. 
Cross-country institutions data (1984-1995)

\begin{tabular}{|c|c|c|c|c|c|c|c|}
\hline & $\begin{array}{l}\text { Labor } \\
\text { Standards }\end{array}$ & $\begin{array}{c}\text { Employment } \\
\text { Protection }\end{array}$ & $\begin{array}{c}\text { Union } \\
\text { Density }\end{array}$ & $\begin{array}{l}\text { Bargaining } \\
\text { Centralization }\end{array}$ & $\begin{array}{l}\text { Ratio of min. } \\
\text { to avg. wage }\end{array}$ & $\begin{array}{c}\text { Benefit } \\
\text { Repl. Rate }\end{array}$ & $\begin{array}{r}\text { Benefit } \\
\text { Duration }\end{array}$ \\
\hline Austria & 5 & 16 & 46.2 & 17 & 0.62 & 0.50 & 2.0 \\
\hline Belgium & 4 & 17 & 51.2 & 10 & 0.60 & 0.60 & 4.0 \\
\hline Denmark & 2 & 5 & 71.4 & 14 & 0.54 & 0.90 & 2.5 \\
\hline Finland & 5 & 10 & 72.0 & 13 & 0.52 & 0.63 & 2.0 \\
\hline France & 6 & 14 & 9.8 & 7 & 0.50 & 0.57 & 3.0 \\
\hline Germany & 6 & 15 & 32.9 & 12 & 0.55 & 0.63 & 4.0 \\
\hline Ireland & 4 & 12 & 49.7 & 6 & 0.55 & 0.37 & 4.0 \\
\hline Italy & 7 & 20 & 38.8 & 5 & 0.71 & 0.20 & 0.5 \\
\hline Netherlands & 5 & 9 & 25.5 & 11 & 0.55 & 0.70 & 2.0 \\
\hline Norway & 5 & 11 & 56.0 & 16 & 0.64 & 0.65 & 1.5 \\
\hline Portugal & 4 & 18 & 31.8 & 7 & 0.45 & 0.65 & 0.8 \\
\hline Spain & 7 & 19 & 11.0 & 7 & 0.32 & 0.70 & 3.5 \\
\hline Sweden & 7 & 13 & 82.5 & 15 & 0.52 & 0.80 & 1.2 \\
\hline UK & 0 & 7 & 39.1 & 6 & 0.40 & 0.38 & 4.0 \\
\hline Canada & 2 & 3 & 35.8 & 1 & 0.35 & 0.59 & 1.0 \\
\hline USA & 0 & 1 & 15.6 & 2 & 0.39 & 0.50 & 0.5 \\
\hline \multicolumn{8}{|l|}{ Europe } \\
\hline Average & 5.15 & 13.77 & 44.52 & 10.77 & 0.54 & 0.61 & 2.38 \\
\hline
\end{tabular}

Note: Data are taken from Nickell and Layard (1999), Tables 6, 7, 9, 10. Labor standards are summarized

in an index whose max value is 10 and refers to labor market standards enforced by legislation. The

employment protection index ranges from 1 to 10 . Union density is measured as a percentage of all

salary earners. Centralization is an index where 17 corresponds to the most centralized regime. Benefit

duration is in years. Europe average: unweighted mean of European countries, except UK.

Table 2: Data on various labor market institutions across OECD countries. Averages for the period 1985-1995. 
Dynamics of Relative Prices and Quantity of Skills in the U.S.

(1963-2002)

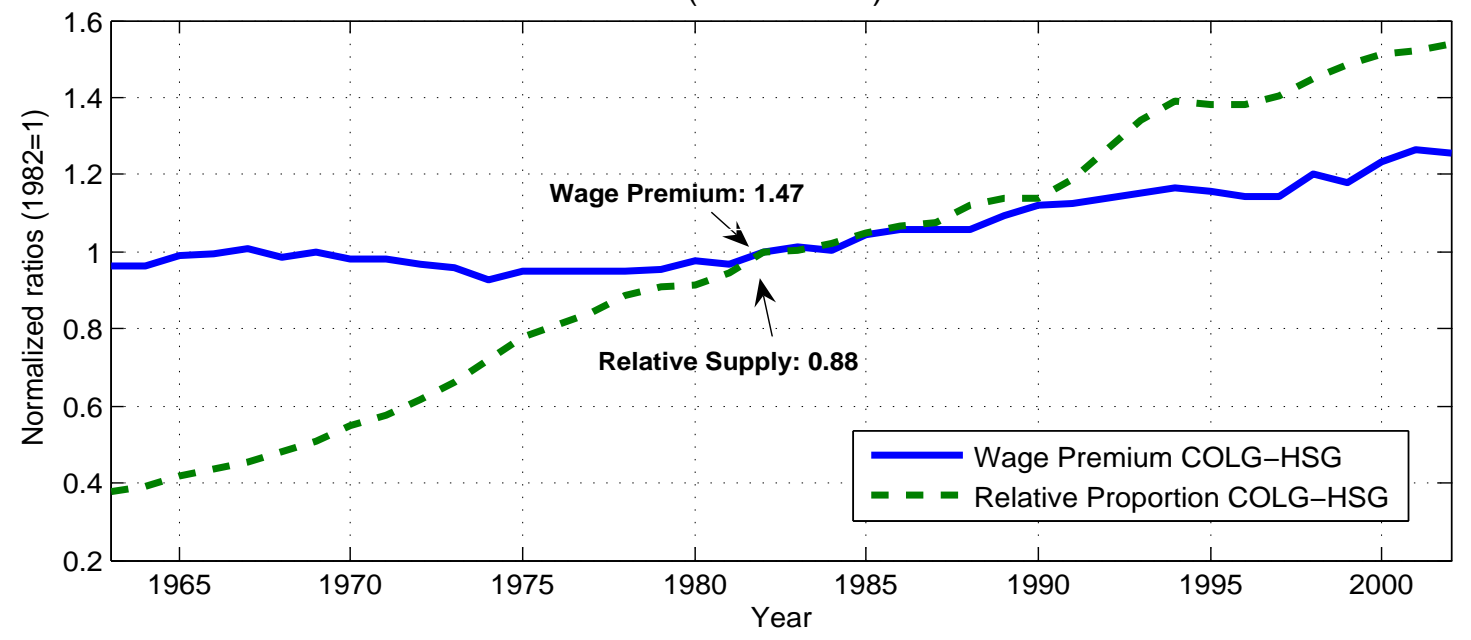

Dynamics of the Gender Gap and the Relative Labor Supply of Women in the U.S. (1963-2002)

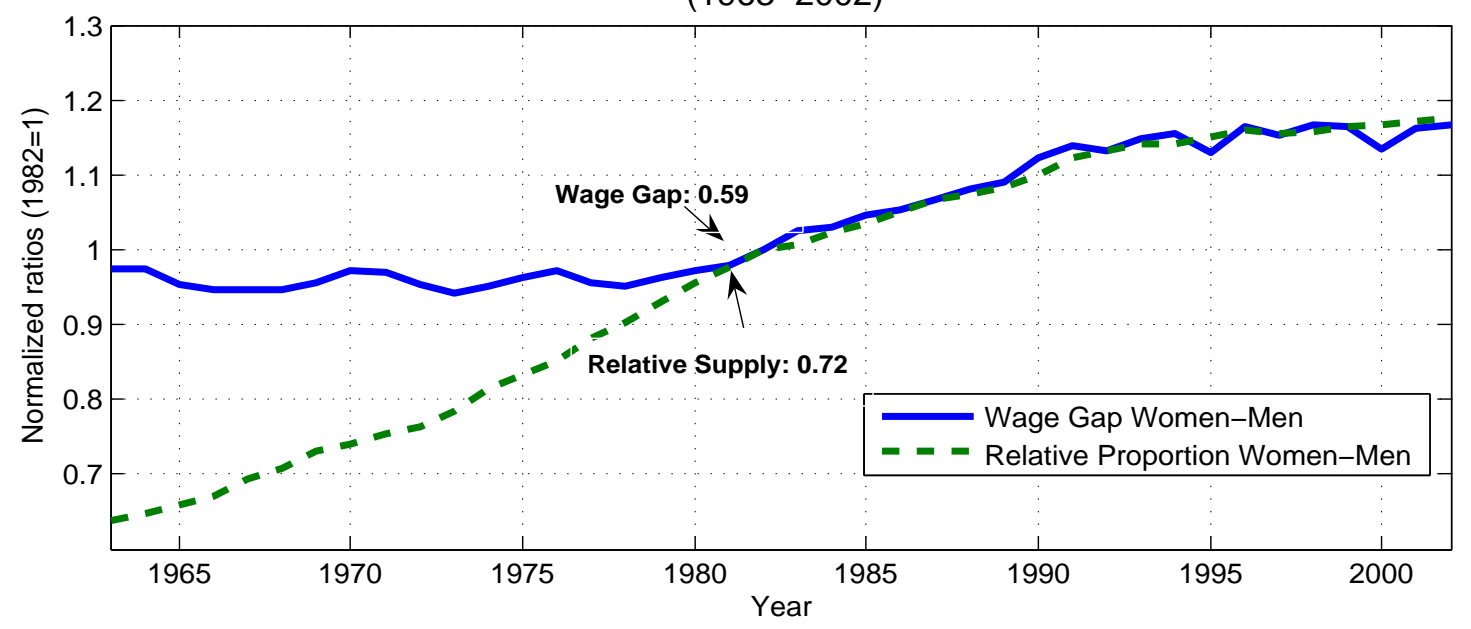

Figure 1: The top panel depicts the evolution of the skill premium (average wage of college graduates relative to the wage of high-school graduates) and of the relative quantity of skilled workers, from 1963-2002. The bottom panel depicts the evolution of the gender gap (average wage of female workers relative to the wage of male workers) and of the relative quantity of female workers, over the same period of time. 


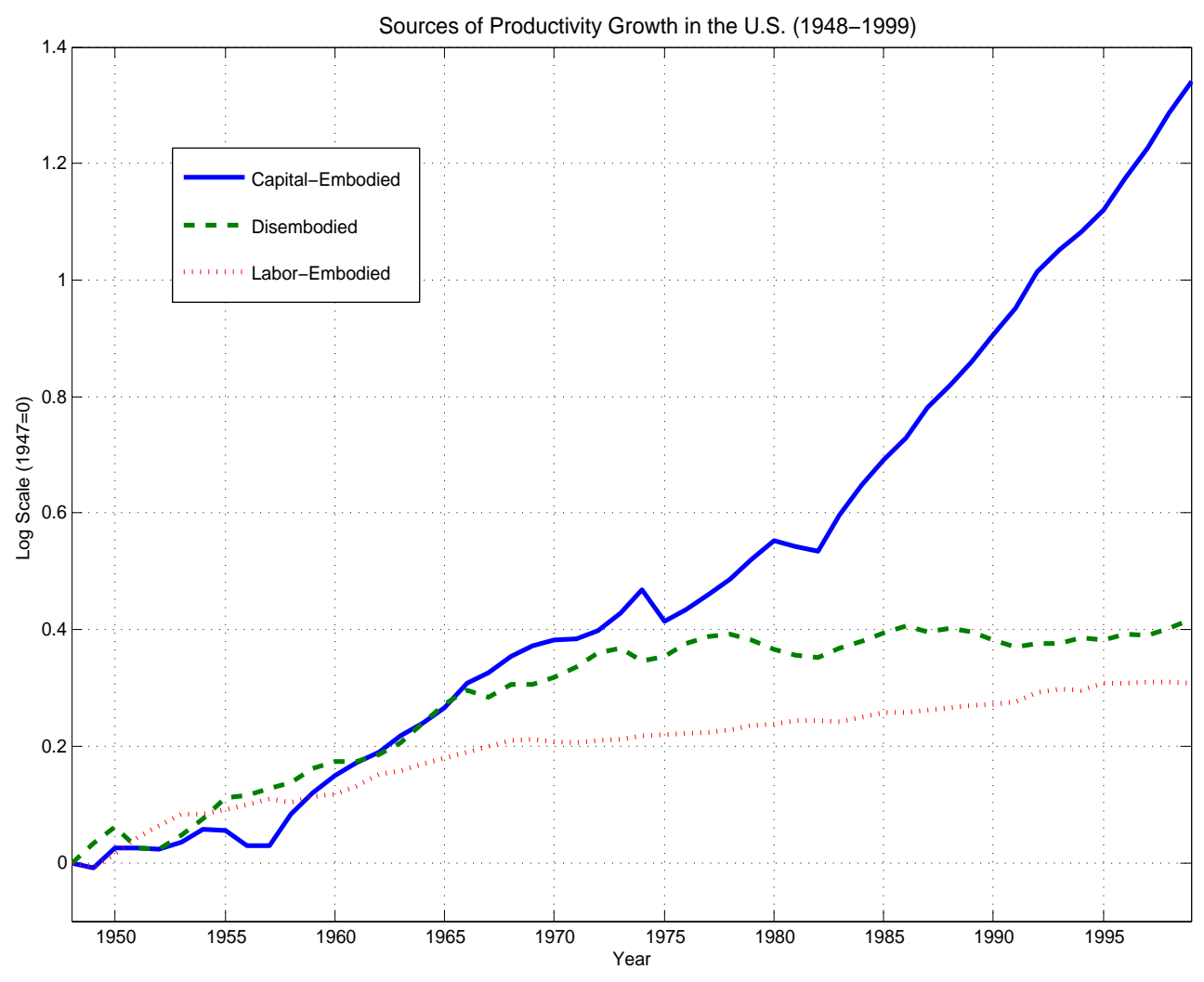

Figure 2: The figure depicts the dynamics of three sources of productivity growth in the postwar U.S. economy: disembodied, capital-embodied, and labor-embodied. Source: Cummins and Violante (2002). 


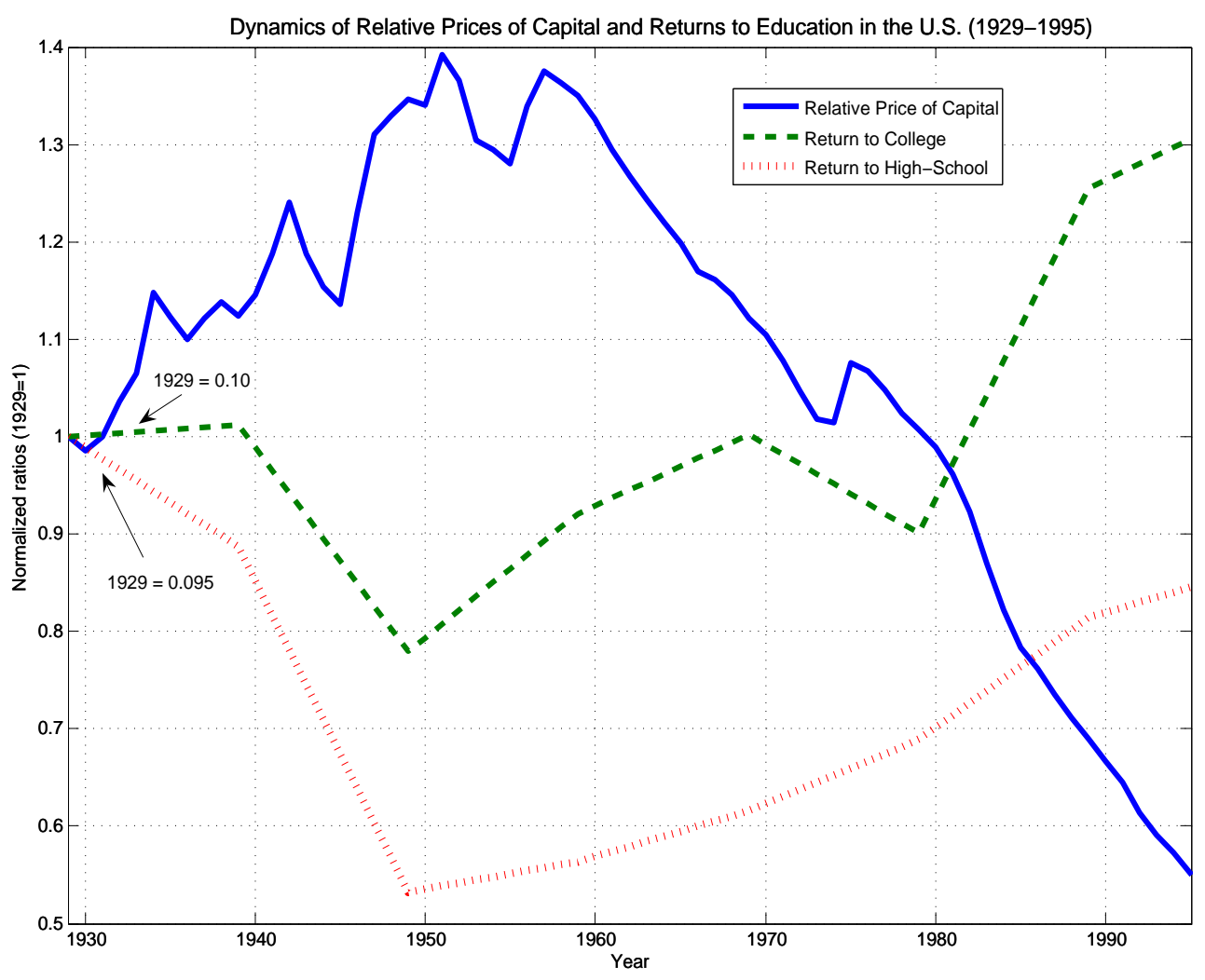

Figure 4: The figure depicts the dynamics of the relative price of capital and the returns to education from 1929-1995 in the U.S. economy. Source: Cummins and Violante (2002) and Goldin and Katz (1999). 